\title{
ESTUDIOS
}

\section{Isla a su Vuelo Fugitiva: Carpentier y el Realismo Mágico*}

$O$ life! I go to encounter for the millionth time the reality of experience and to forge in the smitby of my soul the uncreated conscience of $m y$ race.

Stephen Daedalus, A Portrait of the Artist as a Young Man

il faudrait méditer d'ensemble la possibilité de la route et de la différence comme écriture, l'bistoire de l'écriture et l'bistoire de la route, de la ruptu$r e$ de la via rupta, de la voie rompue, frayée, fracta, de l'espace de reversibilité et de répétition tracé par l'ouverture, l'écart et l'espacement violent de la nature, de la forêt naturelle, sauvage, salvage. La silva est sauvage, salvage. La silva est sauvage; la via rupta s'écrit, se discerne, s'inscrit violement comme différence, comme forme imposée dans la hylé, dans la forêt, dans le bois comme matiè. re; il est difficile d'imaginer que l'accès à la possibilité des tracés routières ne soit pas en même temps accès à l'écriture.

J. Derrida, De la grammatologie

Carpentier permanecerá en La Habana sólo hasta 1945, después de su regreso de Europa en 1939, y los años en Cuba, antes de su partida rumbo a Caracas, serán interrumpidos por dos viajes: uno a Haití en 1943 y

* Una versión abreviada de la parte II del presente trabajo fue leída en la Sesión III - Literatura Cubana- del XVI Congreso del Instituto Internacional de Literatura Iberoamericana, celebrado en la Michigan State University, Eas! Lansing, Michigan, del 26 al 31 de agosto de 1973, bajo la presidencia del profesor Donald A. Yates, de dicha institución. El trabajo forma parte de un libro en preparación sobre Carpentier (y por lo tanto debe considerarse work in progress), 
otro a México en 1944. ${ }^{1}$ Su lugar de residencia fija - La Habana, Caracas- no marcará tanto su obra como los viajes. De éstos hay que destacar cuatro: los dos mencionados, y los viajes al interior de Venezuela en los veranos de 1947 y 1948. ${ }^{2}$ (Habrá otros, en Cuba, a Santiago, sobre todo). De estos últimos surgirá, primero el inconcluso Libro de la Gran Sabana, y luego Los pasos perdidos (1953), textos que señalan la primera, y tal vez única ruptura radical en la trayectoria de la obra de Carpentier. ${ }^{3}$ Por lo tainto, me parece apropiado pensar en el tramo de 1939 , regreso a $\mathrm{La}$ Habana, y 1948, regreso a Caracas después de su segundo viaje a la selva, como una unidad, aunque, a pesar de ser significativas (según se verá), las diferencias entre la literatura carpenteriana de los treinta y la de los cuarenta, no son radicales. ${ }^{4}$

Durante la década de los cuarenta, Carpentier redacta dos libros, La

cuya redacción ha sido facilitada por becas del Latin American Program de Cornell University que me han permitido viajar a Caracas y París en el curso de mis investigaciones. Doy por este medio las gracias a ese organismo, y en particular a su director, el profesor Tom Davis, y a la señora Marta Garciarena de Betancourt, Asesora Técnica del Departamento de Hemeroteca de la Biblioteca Nacional de Venezuela (Caracas), por su amabilidad y ayuda.

1 Para más detalles sobre la biografía de Carpentier ver sus propios testimonios en la entrevista con César Leante, "Confesiones sencillas de un escritor barroco", Cuba, Año 3, No 24 (1964), pp. 30-33, y más recientemente en la entrevista con Joaquín G. Santana, "Muertes, tesurrecciones, triunfos, agonías", Bobemia (La Habana), Año 63, № 13 (26 de marzo de 1971), pp. 5-9. De los años cuarenta queda una entrevista que le hizo, bajo el seudónimo de Lorenzo Tiempo, el poeta y ensayista venezolano Juan Liscano: "Alejo Carpentier: un americano que regresa a América", Papel Literario de El Nacional (Caracas), 16 de septiembre de 1945, p. 2. Todas estas entrevistas, por supuesto, deben ser leídas como textos, no como vías de acceso directo a verdades últimas sobre el escritor y su obra. Desafortunadamente las recopilaciones biográficas que existen sobre Carpentier no practican una lectura de esos textos, sino que se limitan a glosarlos. La única que merece mencionarse, por su cantidad de datos útiles y su excelente bibliografía es la de Klaus Müller-Bergh, Alejo Carpentier. Estudio biográfico-critico (Long Island City: Las Americas Publishing Co., 1972).

2 Para más detalles sobre esos dos viajes a la selva, ver mi "Notas para una cronología de la obra narrativa de Alejo Carpentier, 1944-1954", de próxima aparición en el Homenaje al profesor José J. Arrom que preparan Enrique PupoWalker y Andrew P. Debicki.

3 Tema del siguiente capítulo del presente libro.

4 Estoy de acuerdo con Luis Quesada en que puede pensarse en el período de Ecué-Yamba-O! (1933) hasta El reino de este mundo (1949) como una unidad, dentro de la cual podemos ver dos períodos diferenciados por matices; sólo que los matices son mucho más fuertes y definidos de lo que Quesada sospecha, o tiene tiempo de analizar en una ponencia de simposio. Ver Luis Quesada, "Desarrollo evolutivo del elemento negro en tres de las primeras narraciones de Alejo Carpentier", Literatura de la emancipación y otros ensayos. Memoria del XY Congreso del Instituto de Literatura Iberoamericana (Lima: Universidad Nacional Mayor de San Marcos, Dirección Universitaria de Biblioteca y Publicaciones, 1972), pp. 217-23. No me parece tan radical la diferencia entre la visión del negro en el Carpentier de los años treinta y el de los cuarenta como quiere hacer ver Pedro M. Barreda-Tomas, en su, "Alejo Carpentier: dos visiones del negro, dos conceptos de la novela", Hispania, 55 (1972), pp. 34-44. 
música en Cuba y El reino de este mundo, que se publican en 1946 y 1949 respectivamente, y todos los relatos (con la excepción de $E l$ acoso) que más tarde incluirá en la primera edición de Guerra del tiempo: "Viaje a la semilla", "El camino de Santiago", y "Semejante a la noche", además de otros dos que no recogerá en volumen, "Los fugitivos" y "Oficio de tinieblas". 5 Con estas narraciones empezará Carpentier a ser reconocido en Hispanoamérica y el extranjero como escritor de relieve, no simplemente como uno más de tantos autores de un libro oscuro. La década de los cuarenta es la más prolífica de Carpentier hasta la fecha, y en más de un sentido la más importante.

$\mathrm{Si}$ bien los relatos y $\mathrm{El}$ reino de este mundo son las obras de este periodo que mayor interés encierran para la crítica, el libro que da tono a esos años, y el que los distingue de los años de la vanguardia y el Afroantillanismo, es La música en Cuba; obra en que traza la evolución histórica del arte musical cubano - tanto popular como de minoríasdesde la colonia hasta el presente. Este período incluye, además, los únicos experimentos de Carpentier con la literatura fantástica, y será asociado con lo que la crítica alternativamente ha llamado "realismo mágico" o "lo real maravilloso americano" (rúbrica creada por el propio Carpentier). Los viajes de 1947 y 1948 por la selva venezolana y el fallido intento de escribir un libro de viajes a raíz del primero - Libro de la Gran Sabanacerrarán el período, al llevar hasta sus límites las posibilidades que la vanguardia habia abierto a un tipo de narración en Hispanoamérica. Los textos del período guardan las huellas de esa ruptura.

La Hispanoamérica de los años cuarenta a la que ingresa Carpentier es, para los intelectuales y artistas que como él habían vivido la vanguardia europea, ya sea en Europa misma o desde el Nuevo Mundo, la Hispanoamérica del regreso y la re-inmersión. Con Carpentier regresan de Europa - sobre todo de Francia y España-, después de la caída de la República española, y con el comienzo de la Segunda Guerra Mundial, gran número de artistas e intelectuales hispanoamericanos, y como él mismo señala en los ensayos para Carteles, numerosos artistas e intelectuales europeos. Las consecuencias de este regreso alrededor de 1940 , y de la emigración de intelectuales europeos a América (sobre todo españoles republicanos exilados) ya han sido esbozadas por Emir Rodríguez Mone-

5 Los datos específicos y cronología de la publicación y redacción de estos relatos podrá encontrarse en "Notas para una cronología de la obra narrativa de Alejo Carpentier, 1944-1954", op. cit. 
gal:6 se crean casas editoras, se fundan revistas, surgen nuevos grupos de intelectuales en las grandes capitales del continente (en Cuba, por ejemplo, el grupo de la revista Orígenes, fundada en 1944, al cual se verá vinculado, aunque marginalmente, Carpentier). El fenómeno, uno de los más significativos en la historia cultural hispanoamericana en lo que va de siglo, tiene otras consecuencias importantes. Rodríguez Monegal escribe: "al mismo tiempo [surge], un crecimiento de la conciencia nacional -que había tenido sus manifestaciones más notables en México después de la revolución, para poner un ejemplo conocido- estimula la obra de ensayistas que se vuelcan cada vez con más ahinco en una doble indagación: del ser del país y del ser latinoamericano". ${ }^{7}$ De hechó, lo más importante del fenómeno histórico mencionado es que, al quedar relativamente desvinculada América de Europa, y tener que reconcentrarse sobre sí misma, las tendencias autonomistas en el plano de la cultura, que como se ha visto se habían intensificado durante los años de la vanguardia, se acendran aún más - la historia provee el corte deseado. El corte de amarras, el salto al vacio, traerá una preocupación vehemente por definir el rumbo que se ha seguido en el pasado, y demarcar la ruta que ha de seguirse en el futuro. Los ensayos de Carpentier sobre el "ocaso" de Europa no son sino uno de muchos síntomas de lo que constituirá en Hispanoamérica todo un movimiento mundonovista: movimiento que con mayor o menor militancia se esfuerza por definir lo americano en sus propios términos, y que se dedica activamente a rescatar el pasado y la tradición hispanoamericanos. Los años cuarenta son el período de la búsqueda de la conciencia americana, del esfuerzo por desentrañar los orígenes de la historia y del ser hispanoamericanos para fundar sobre ellos una literatura propia, distinta de la europea -el porvenir no se verá ya como el patrimonio de una sola raza, que por su espontaneidad primitiva es detentora del poder y la fuerza, tesis de "El milagro de Anaquillé", sino como la fusión de todas las razas y culturas del continente en una nueva entidad histórica. Son los años del Contrapunteo cubano del tabaco y el azúcar (1940), de Fernando Ortiz, libro que ofrece una interpretación estructural de la historia cubana, que tecoge y monta a manera de collage numerosos textos coloniales de diversas procedencias, mosaico histórico-cultural; de La viltima Tule, de Alfonso Reyes, que retoma, en otro registro, la labor iniciada por Vasconcelos y Ramos, y que recoge el tema de la utopía de América y de su lugar en la historia universal; de dos libros funda.

" "La nueva novela latinoamericana", Actas del Tercer Congreso Internacional de Hispanistas (México: El Colegio de México, 1970), pp. 47-48.

7 Ibid., p. 48. 
mentales de Pedro Henriquez Ureña, Historia de la cultura en la América Hispánica (1947), y Las corrientes literarias en la América Hispánica (1949, versión inglesa original de 1945), que intentan mostrar la unidad y continuidad histórico-cultural de Hispanoamérica; de Hacia una filosofía americana (1945), de Leopoldo Zea, discípulo de Gaos, recién emigrado a México (1944), que indaga las posibilidades de pensamiento que surja de la circunstancia americana; del ensayo de Mariano Picón-Salas, De la conquista a la independencia (1944), donde se intenta dar un panorama coherente de la historia de las artes y el pensamiento hispanoamericanos antes de la fundación de las repúblicas. Aunque la mayoría de estos libros se escriben al estilo de kulturgescbicbte, la década se cierra (y abre a otras investigaciones de la misma índole) con El laberinto de la soledad (1950), en que Octavio Paz, aprovechando nuevas perspectivas derivadas de Heidegger, cuyo Ser y el tiempo acababa de traducir Gaos, interpreta la historia y la cultura mexicanas como productos del desarraigo. Quizás pueda tomarse como programática el exordio con que Pedro Henríquez Ureña abre el primer capitulo de Las corrientes literarias en la América Hispánica:

En una época de duda y esperanza, cuando la independencia política aún no se había logrado por completo, los pueblos de la América hispánica se declararon intelectualmente mayores de edad, volvieron los ojos a su propia vida y se lanzaron en busca de su propia expresión. Nuestra poesía, nuestra literatura, habían de reflejar con voz auténtica nuestra propia personalidad. Europa era vieja; aquí había una vida nueva, un mundo para la libertad, para la iniciativa y la canción. Tales eran la intención y el significado de la gran oda, la primera de las Silvas americanas, que Andrés Bello publicó en 1823. Bello no era un improvisador, un advenedizo del romanticismo; era un sabio, un gran gramático, traductor de Horacio y de Plauto, explorador adelantado en las selvas todavía vírgenes de la literatura medieval. Su programa de independencia nació de una meditación cuidadosa y un trabajo asiduo. Desde entonces, nuestros poetas y escritores han seguido en la búsqueda, acompañados, en años recientes, por músicos, arquitectos y pintores.

En las páginas que siguen hemos de ver cómo se ha cumplido este deber, y hasta qué punto se han colmado esas esperanzas. ${ }^{8}$

Los dos libros de Hentíquez Ureña; el de Picón-Salas, y los de Zea y

8 (México: Fondo de Cultura Económica, 1949), pp. 9-10. 
Paz (en su segunda edición; la primera es de Cuadernos Americanos) aparecen en el Fondo de Cultura Económica de México; el de Zea en las recién fundadas Jornadas, colección en la que aparecerían durante la década de los cuarenta numerosos trabajos de exégesis continental en todos los niveles: político, económico, social, literario, filosófico, etc.; la Historia de la cultura en la América Hispánica en la también recién fundada colección Tierra Firme, donde aparecerá, en 1946, La música en Cuba, libro que se inscribe de lleno en la tendencia que he venido esbozando. ${ }^{9}$

La música en Cuba le fue comisionado a Carpentier en 1944 por Daniel Cossío Villegas (que dirigía a la sazón la colección Tierra Firme), cuando el escritor cubano se encontraba de vacaciones en México. ${ }^{10}$ Pero las investigaciones sobre la historia de la música cubana habían empezado años antes, desde la llegada de Carpentier a La Habana en 1939, y habían continuado con motivo del viaje a Haití en $1943 .{ }^{11}$ Lo importante es subrayar, sin embargo, que esas investigaciones, y el libro que de ellas se deriva, surgen del deseo de explorar, descubrir y preservar la tradición hispanoamericana, específicamente la cubana, y fijar su particularidad: "Huérfana de tradición artística aborigen, muy pobre en cuanto a las plás. ticas populares, poco favorecida por los arquitectos de la colonia - si la comparamos, en este terreno, con otras naciones de América Latinala isla de Cuba ha tenido el poder de crear, en cambio, una música con fisonomía propia que, desde muy temprano, conoció un extraordinario éxito de difusión" (p. 9). Carpentier se ve forzado a rescatar esa historia de viejas crónicas y compendios, de manuscritos y papeles olvidados: "emprendimos el paciente examen de archivos de catedrales - de Santiago y La Habana, principalmente-, de actas capitulares de iglesias y ayuntamientos, de armarios de parroquias (con brillantes resultados en Santiago, por ejemplo, o nulos en Santa María del Rosario), de documentos manuscritos, de bibliotecas privadas, de colecciones particulares, de estantes de librerías de viejo, revisando a fondo los periódicos, gacetas y revistas coloniales" (p. 11). Regresa, además, sobre la Historia de las Indias de Bartolomé de las Casas, la Historia general y natural de las Indias de Fernández de Oviedo, la Verdadera bistoria de Bernal Díaz; lee las dos

\footnotetext{
9 Quisiera expresar por este medio mi agradecimiento al profesor (emeritus) de Cornell, Dalai Brenes, por el obsequio de un ejemplar de esta primera edición de La música en Cuba. De ahora en adelante se pondrá en el texto, entre paréntesis, el número de página de todas las citas de este libro, que provienen de esa edición. Lo mismo se hará con $E l$ reino de este mundo, del que se emplea la edición de 1969 de la Cía. General de Ediciones de México, y de Guerra del tiempo, edición de 1966 de la misma editorial.

10 Testimonio de Carpentier al autor en París en mayo de 1973.

11 Idem.
} 
crónicas cubanas de la colonia, la Historia de la Isla y Catedral de Cuba, de Morell de Santa Cruz, y la Llave del nuevo mundo de Arrate; revisa compendios más recientes, como la Crónica de Santiago de Cuba de Bacardi, la Memoria sobre la vagancia en la Isla de Cuba de José Antonio Saco, la Historia de la Habana de Roig de Leuchsenring, así como los trabajos de Fernando Ortiz y Ramito Guerra. Lee, además, historias de Haití, como la Description de L'Isle de Saint Domingue de Moreau de Saint Méry, y otras, de donde saldrán Monsieur Lenormand de Mezy y demás personajes de El reino de este mundo. Difícilmente podría exagerarse la importancia de todo este trabajo de investigación para la obra narrativa de Carpentier.

Con las investigaciones y redacción de $L a$ música en Cuba irrumpe la historia en la narrativa carpenteriana -Ecué-Yamba-O!, "Histoire de Lunes", "El milagro de Anaquille”", reflejan, sin precisión histórica, hechos contemporáneos o relativamente próximos al autor. La música en Cuba le proporciona a Carpentier un método de trabajo, que consiste en $\mathrm{Ja}$ investigación histórica, en la creación a partir de una tradición que él va rehaciendo con la ayuda de textos de diversa índole. Más específicamente, le da un nuevo cauce a su ficción, que será la búsqueda en esos textos olvidados de personajes oscuros, de biografías incompletas, que él completará en sus relatos con sólida documentación y rigurosa y (casi) comprobable cronología. Todos los relatos que Carpentier escribe en los años cuarenta parten de las investigaciones históricas hechas con motivo de $L a$ música en Cuba, y de ahora en adelante (1946), toda ficción carpenteriana va a girar en torno a la biografía imaginaria (o seudo-histórica) de un personaje que Carpentier rescata del olvido (con la notable excepción de Los pasos perdidos, en que el biografiado es, significativamente, el propio Carpentier): desde el Marqués de Capellanías a Henri Christophe y Monsieur Lenormand de Mezy, desde el protagonista de $E l$ acoso hasta Víctor Hughes, todos los protagonistas de Carpentier llevarán esa marca - sus vidas serán notas escritas en el margen de todos esos tomos que Carpentier maneja en tan diversos lugares.

Hay otro cambio significativo durante los cuarenta en la narrativa de Carpentier que tiene una relación directa con las investigaciones realizadas para la redacción de La música en Cuba: el estilo. En Ecué-Yamba-O!, en "Histoire de Lunes", en "El milagro de Anaquille", la prosa de Carpentier está llena de reflejos estilísticos de la extrema vanguardia: metáforas arriesgadas, adjetivos inusitados, onomatopeyas, ritmo entrecortado. En los años cuarenta, su prosa se va despojando de esos recursos (aunque, desde luego, nunca llega a perder algunos de ellos), hasta convertirse 
en esa prosa añeja, arcaizante, recargada y barroca que lo distingue desde entonces. El paso es gradual, perceptible, y sirve para fechar aproximadamente la redacción de los relatos de la época. ${ }^{12} \mathrm{El}$ Carpentier que escribe en "Semejante a la noche": "Con bordoneos de vihuela y repique de tejoletas, festejábase, en todas partes, la próxima partida de las naves. Los marinos de La Gallarda andaban ya en zarambeques de negras horras, alternando el baile con coplas de sobado..." (p. 114), no es el mismo de Ecué-Yamba-O!, como tampoco el de "Los fugitivos" y "Oficio de tinieblas", que son los cuentos de la década del cuarenta que más relación guardan todavía con su obra anterior. La transformación estilística no podía ser más notable, ni su relación con la lectura de tantos textos coloniales más evidente. La ficción carpenteriana no será mera evocación de un pasado, simple rescate de unos orígenes sepultados por el tiempo, sino que querrá ser pastiche de esos textos en que se encierra la memoria hispanoamericana, repetición, re-elaboración textual en el sentido más concreto y tangible.

Busca de orígenes, rescate de la historia y la tradición, fundación de una conciencia americana autónoma, elaboración de una literatura fiel a los ritmos de una América erguida por sí sola y poseedora de un espíritu propio, síntesis de las diversas razas y culturas que la habitan; esa será la intención de Carpentier, el sentido de su empresa artística durante los años cuarenta. Carpentier, como un Ulises americano, se lanza a su realización por las sinuosas carreteras, los polvorientos caminos y los turbulentos ríos del continente. Pero también por las laberínticas filigranas de textos carcomidos, roídos por el tiempo y el polvo del olvido. La problemática se instalará precisamente en la disparidad de los itinerarios de esas jornadas, la que va por caminos de papel y secos ríos de tinta, y la de los ríos caudalosos y montes inexpugnables. Santa María del Rosario, La Habana, Santiago de Cuba, Caracas, Port-au-Prince, Ciudad Bolivar, Santa Elena; Moreau de Saint Méry, Las Casas, Oviedo, Gumilla, Schomburgk, Bacardí, Humboldt... ningún viaje setá suficiente, ninguno bastante largo, y ningún itinerario señala a Itaca como destino. Lo que queda de esos viajes son los textos, las huellas sobre los otros caminos se borran, con sus contradicciones y sus ambigüedades, con sus enigmáticas repeticiones y circularidades. Pero en esos textos se juega el destino de la literatura narrativa hispanoamericana, suspendida entre los origenes perdidos y la historia, entre la fábula y la crónica, entre la presencia cabal del

12 Ver, "Notas..." op. cit. 
hombre en el reino de este mundo y su cifra en una escritura que se resiste a toda simplificación, y a servir de acceso fácil a la utopia.

De la labor de esos años queda un texto teórico que resume otros menores publicados a lo largo de la década, y que ha alcanzado inusitada fortuna. Antes de pasar al análisis de las obras de los años cuarenta, precisa verse, en toda su problematicidad, las reverberaciones históricas, previas y posteriores, del prólogo de El reino de este mundo.

\section{II}

des rayons transfigurants d'une grâce que je persiste en tout point à opposer à la grâce divine.

A. Breton

El mundo de lo divino no cesa de fascinarnos parque más allá de la curiosidad intelectual, bay en el hombre moderno una nostalgia.

O. Paz

Si nos dejásemos persuadir por los datos que a primera vista ofrece la historia literaria, habría que declarar que la obra de Carpentier responde a lo que indistintamente se ha llamado "realismo mágico" o "lo real maravilloso", desde la publicación en 1948 del ensayo que un año después aparecerá como prólogo de El reino de este mundo, y que se conoce bajo el título, "De lo real maravilloso americano".13 Pero los datos que vinculan a Carpentier con ese concepto no despliegan la continuidad que la relación histórica de un movimiento literario o crítico exige. Por ejemplo, cuando en 1955 Angel Flores publica el artículo que echa a rodar el concepto por claustros y congresos académicos, Carpentier no figura entre los escritores mencionados. ${ }^{14}$ No será sino hasta la década de los

1s El Nacional (Caracas), 8 de abril de 1948, p. 8. La primera edición de El reino de este mundo es de México: EDIAPSA, 1949.

14 "Magical Realism in Spanish American Fiction", Hispania, 38 (1955), pp. 187-92. Después del artículo de Flores han aparecido, que yo sepa, los siguientes: Luis Leal, "El realismo mágico en la literatura hispanoamericana", Cuadernos Americanos, 153 (1967), pp. 230-35; Angel Valbuena Briones, "Una cala en el realismo mágico", Cuadernos Americanos, 166 (1966), pp. 233-41; E. Dale Carter, "Breve reseña del realismo mágico en Hispanoamérica", Antología del realismo mágico. Ocho cuentos hispanoamericanos (Nueva York: Ódyssey Press, 1970), pp. xi-xv. Sobre Carpentier especificamente se han publicado los trabajos siguientes: Fernando Alegria, "Alejo Carpentier: realismo mágico", Humanitas, 1 (1960), 345-72; Carlos Santander T., "Lo maravilloso en la obra de Alejo Carpentier", 
sesenta, debido a la reimpresión del citado prólogo en Tientos y diferencias (1964) y a las repercusiones del boom de la novela hispanoamericana, que Carpentier empezará a ser estudiado como precursor, teórico y practicante del realismo mágico. Resulta irónico, a mi modo de ver, ese postergado rescate, porque en los sesenta, cuando publica El siglo de las luces, Carpentier hace años que no escribe relatos que puedan denominarse mágicorrealistas; a no ser que, violentando el concepto se le haga abarcar toda narrativa que no se ciña a los cánones más estrictos del realismo del siglo xrx. Debe tenerse presente que, como ya se ha apuntado, todos los relatos fantásticos que Carpentier incluye en Guerro del tiempo datan de los años cuarenta. ${ }^{15}$ Pero la confusión que ese tardio rescate de Carpentier consiente no se debe únicamente al desconocimiento de datos como los anteriores, sino a que el realismo mágico ha descrito una accidentada y compleja, si bien pobre, trayectoria histórica. Dar a esa historia la lisura propia de la fábula equivaldría a convertir en mágicorrealista a la crítica, pero la única magia que se lograría conjurar sería la de la mixtificación. Hay que restaurar los accidentes, los silencios y las caídas de la verdadera historia del realismo mágico, para poder determinar cómo se inserta en ella la obra de Carpentier.

Me refiero aquí al realismo mágico como concepto crítico -utilizando la terminología de René Wellek - no a la literatura que algunos un poco a la ligera han dado en llamar mágicorrealista; y si intento aclarar de una vez por todas los orígenes del concepto no lo hago con el propósito de dar con la verdadera ortodoxia mágicorrealista. Lo que merece preservarse del realismo mágico no es lo central del concepto, pues como se verá, éste es un vacío teórico y a veces una nulidad histórica, sino sus reflejos, que son síntomas de una problemática mucho más relevante en la historia de las letras y de las ideas en Hispanoamérica: el dilema de la ubicación de América en la historia universal, que había sido replanteado por la vanguardia a raiz de la diseminación en castellano de las

Atenea, N' 42 (1965), pp. 99-126; Suzanne Jill Levine, "'Lo real maravilloso' de Alejo Carpentier a García Márquez", Eco, 20 (1970), pp. 565-76; Emir Rodríguez Monegal, "Alejo Carpenticr: lo real y lo maravilloso en El reino de este mundo", Revista Iberoamericana, 37 (1971), 619-49, reproducido en Asedios a Carpentier. Once ensayos criticos sobre el novelista cubano, ed. Klaus Müller-Bergh (Santiago de Chile: Editorial Universitaria, 1972), pp. 101-32.

15 Santander, op. cit., por ejemplc, es uno de los críticos que estudia los relatos de Guerra del tiempo como posteriores a Los pasos perdidos, pero no es el único, ya que rara vez la crítica, aún en los trabajos de más amplio diseño, se ha preguntado si existe una evolución visible en la obra madura de Carpentier. EI propio autor (aunque desde luego, no le incumbe a él señalarlo) nunca habla de su obra madura -es decir todo menos Ecué-Yamba-O!- sino como un bloque uniforme. 
obras de dos filósofos que ofrecían estimulantes aunque contradictorias soluciones: Spengler y Hegel. ${ }^{16}$ Tomo por sentado, además, que el concepto se refiere a la literatura narrativa, no a la poesía, y específicamente a la narrativa fantástica o poética. Si algo podemos sacar en limpio de la accidentada historia del realismo mágico en Hispanoamérica, es que se trata de un esfuerzo por explicar una narrativa que, sin entrar por el momento en mayor detalle, podemos considerar fantástica. Una narrativa, pues, que no dependa de: 1) las leyes naturales o físicas; 2) la percepción usual, cotidiana (burguesa, occidental), de la naturaleza y del hombre. Es decir, una narrativa, unos relatos, en que la relación no esté fundada o justificada por el reflejo del mundo físico o social. ${ }^{17}$

El realismo mágico, o lo real maravilloso, aflora en tres momentos del siglo $\mathrm{Xx}$. El primero es europeo, los dos últimos hispanoamericanos (simplifico, por supuesto, ya que hay ramificaciones en los Estados Unidos e Italia que no caen de lleno en estos tres momentos). ${ }^{18}$

\footnotetext{
16 Aunque según Leopoldo Zea (Esquema para una bistoria de las ideas en Hispanoamérica, México, Imprenta Universitaria, 1956, caps. II y III) la obra de Hegel tuvo escasa circulación en el Nuevo Mundo durante el siglo xIx, la obra de Spengler, que puede verse en conjunto como una reacción contra el autor de la Fenomenología del espiritu, pone de moda el problema de la ubicación de América en la historia universal a partir de la traducción en 1923 de La decadencia de Occidente. Desde la "Introducción" Spengler formula problemas que habían causado candentes polémicas desde la Conquista: "Y en cuanto a las grandes culturas americanas, han sido, sin más ni más, ignoradas, so pretexto de que les falta conexión; ¿con quée"' (Madrid: Espasa Calpe, 1923, I, 41). En los mismos años veinte; en el 28, José Gaos tradujo la Filosofía de la bistoria de Hegel, en donde América ocupa un problemático lugar — prehistoria o futuro-n, dando fuerza a un debate cuyo fin no se vislumbra aún. Véase el ensayo de José Ortega y Gasset, "Hegel y América" [1928], en donde el filósofo español discute la idea de América como futuro; ensayo que sigue teniendo repercusiones en el pensamiento hispanoamericano, por ejemplo, en Zea, En torno a una filosofía americana, Jornadas, 52 (México: Fondo de Cultura Económica, 1945), y sobre todo en Octavio $\mathrm{Paz}$, "Literatura de fundación", Puertas al campo (México: UNAM, 1966), 11-19. 17 Véase la útil tentativa clasificatoria de Tzvetan Todorov, Introduction à la litérature fantastique (París: Seuil, 1970). La utilidad de la obra de Todorov, precisamente como introducción, es indiscutible, pero su tenaz negativa metodológica de formularse las preguntas más difíciles lo lleva a decir banalidades como la siguiente: "La foi absolue comme l'incredulité totale nous méneiraient hors du fantastique; c'est l'hesitation qui lui donne vie" (p. 35). [Véase crítica de Ana María Barrenechea al libro de Todorov en $R . I$. No 80$]$.

18 Ver, sobre todo, Alfred H. Barr, Painting and Sculpture in the Museum of Modern Art (Nueva York; Museum of Modern Art, 1942), y American Realists and Magic Realists: ed. Dorothy C. Miller and Alfred H. Barr (Nueva York: Museum of Modern Art, 1969 [1943]). Valbuena Briones, en el artículo citado, menciona la obra de Massimo Montempelli en Italia. Para más información sobre éste $\mathrm{y}$ otros aspectos de los temas bajo análisis, ver, Emir Rodríguez Monegal, "Realismo mágico vs. literatura fantástica: un diálogo de sordos", de próxima aparición en las Actas del XVI Congreso de literatura hispanoamericana, celebrado en East Lansing, Michigan en agosto de 1973 (ver nota inicial).
} 
El primer momento es el de la vanguardia europea, cuando surge el término en el libro de Franz Roh Nacb-Expressionismus (Magischer Realismus), y cuando los surrealistas, especificamente Breton en el primer Manifeste (1924), proclaman lo maravilloso como categoría estética y hasta como modo de vida. De este primer momento sólo queda en Hispanoamérica la brillante exposición de Borges en su ensayo "El arte narrativo y la magia" (1932).

El segundo momento pertenece a la Hispanoamérica de los años cuarenta, cuando el término ya había pasado de moda en Europa, y había encontrado acogida tardía entre críticos de arte norteamericanos. Este brote ocurre, en Hispanoamérica, alrededor de 1948, cuando Uslar Pietri y Carpentier, casi simultáneamente, desempolvan el viejo cartel de los años de la vanguardia (ambos habían coincidido en París en la década de los veinte, y en Venezuela a fines de los cuarenta; Uslar, ${ }_{2}$ sin embargo, pasa una temporada en la Columbia University de Nueva York, y es concebible que haya renovado su contacto con el término allí, recogiéndolo de los críticos de arte mencionados). Uslar Pietri adopta la fórmula de Roh, aunque sólo de pasada, en un ensayo de escaso interés hoy, salvo para aquellos que se ocupen de la historia del cuento venezolano; ${ }^{19}$ Carpentier, por su parte, adapta la versión surrealista para crear el trinomio, lo "real maravilloso americano". Lo que provoca en los años cuarenta la resurrección del venerable oxímoron es: 1). por una parte el impulso mundonovista, que lleva al intento de formular las bases de una literatura que sea auténticamente hispanoamericana, y 2) el deseo, por parte de escritores vanguardistas y a la vez de izquierda, de preservar el legado de la vanguardia contra los embates de otro binomio que había alcanzado vigencia en los años treinta, y. que las corrientes neo-existencialistas, enroladas, de la segunda postguerra de nuevo esgrimían -el realismo socialista. ${ }^{20}$ José Antonio Portuondo tuyo el gran acierto de mostrar la

19 "Lo que vino a predominar en el cuento y a marcar su huella de una manera perdurable fue la consideración del hombre como misterio en medio de los datos realistas. Una adivinación poética o una negación poética de la realidad. Lo que a falta de otra palabra podría llamarse un realismo mágico". Letras y bambres de Venezuela (México: Fondo de Cultura Económica [Colección Tierra Firme, № 42], 1948), p. 161.

20 Rodríguez Monegal, "Lo real y lo maravilloso..." op. cit., ya ha notado la alusión negativa que hay en el prólogo a El reino de este mundo a Sartre y sus discípulos: "No por ello va a darse la tazón, desde luego, a determinados partidarios de un regreso a lo real -término que cobra, entonces, un significado gregariamente político-, que no hacen sino sustituir los trucos de prestidigitador por los lugares comunes del literato 'enrolado' o escatológico regodeo de ciertos existencialistas" (p. 12). 
oposición entre realismo mágico y realismo socialista en un artículo suyo publicado en 1952, y apenas citado hoy. ${ }^{21}$

El tercer momento del realismo mágico, que pudiera denominarse crítico-académico, parte del artículo de Flores antes citado, pero alcanza vigor y difusión de los sesenta, cuando la crítica busca las raíces hispanoamericanas de algunas novelas del Boom y anteriores a éste, y trata de explicarse y justificar el carácter experimental de las mismas. Desde el artículo de Flores estos esfuerzos rara vez han pasado de ser descripciones de rasgos propios de la literatura de vanguardia, frecuentemente a guisa de ser explicaciones de fenómenos literarios autóctonos de Hispanoamérica. En el caso de Flores encontramos sobre todo lo primero: en su artículo lo que se destacan son los rasgos más obvios de la literatura de vanguardia (con especial atención al legado de Kafka), y su asimilación por un grupo de escritores hispanoamericanos que rompen, según él a partir de 1935, con la tendencia nativista. Pero como concepto crítico, el realismo mágico que describe Flores no tiene ni la especificidad definitoria, ni el vuelo teórico necesarios para ser convincente y útil. ¿Cómo puede afirmar Flores que los mágicorrealistas se aferran a la realidad para evitar que la literatura penetre sus obras $e$ incluit entre éstos a Borges?22 Tal vez sea injusto hacer estas preguntas a un trabajo que más que nada celebra (tardíamente) la llegada de la vanguardia a la literatura hispanoamericana. Los trabajos que le siguen, sin embargo, intentan no ya celebrar el legado vanguardista, sino apropiárselo - se recoge ahora el legado de Carpentier. Los resultados, sin embargo, siguen siendo poco satisfactorios. Luis Leal, por ejemplo, sostiene que el realismo mágico "no puede ser identificado ni con la literatura fantástica ni con la literatura sicológica, pero tampoco con el surrealismo o la literatura hermética que describe Ortega. El realismo mágico no se vale, como el sobrerrealismo, de motivos oníricos; tampoco desfigura la realidad o crea mundos imaginados como lo hacen los que escriben literatura fantástica o ciencia ficción. .."233 Semejantes negaciones parecen algo precipitadas si consideramos que Leal pasa a incluir a Juan Rulfo entre los mágicorrealistas; porque si el que los personajes hablen después de muertos en Pedro Páramo no

21 "La realidad americana y la literatura" (contiene inciso intitulado "Realismo mágico"), El beroísmo intelectual (México: Tezontle, 1955), pp. 125-36; ver en especial 135-36. Valbuena Briones, op. cit., es el único en recordar este trabajo, que por otra parte, alude en especial a la literatura norteamericana.

2.2 "The practitioners of magical realism cling to reality as if to prevent 'literature' from getting in their way, as if to prevent their myth from flying off, as in fairy tales, to supernatural realms". Op. cit., p. 191.

23 Leal, op. cit., p. 231. 
es algo sobrenatural o fantástico, entonces precisamos definiciones más rigurosas que las provistas por Leal. $\mathrm{Y}$, ¿no hay motivos oníricos en Carpentier, en $E l$ reino de este mundo, por ejemplo? Para Leal no sólo se trata de que lo real maravilloso exista en Hispanoamérica, sino que los escritores presentan esas "realidades" sin cuestionarlas, desde la perspectiva de los llaneros, o de los campesinos que creen a pie juntillas que los muertos hablan. Pero, ¿qué tiene de específicamente hispanoamericano esta definición? ${ }^{24}$ Los esfuețzos por domar el legado vanguardista a un molde hispanoamericano han sido tenaces, pero pocos han sido los que han logrado mantenerse sobre el potro. Más recientemente; en un artículo de documentación histórica más amplia y firme que la de Leal, Angel Valbuena Briones vuelve sobre el tema, afirmando también el carácter hispanoamericano del realismo mágico, pero incluyendo ahora (como había hecho Flores) a Borges y a Cortázar, sin detenerse a considerar la problemática y tal vez crítica diferencia entre la literatura (o tal vez la teoría) de éstos y la de orientación primitivista en Carpentier y As. turias. $^{25}$ La difusión del concepto durante este tercer momento, como era de esperar, ha rebasado los límites de la crítica académica, y algunos escritores más recientes han aumentado la confusión invocándolo en declaraciones periodísticas. Gabriel García Márquez, por ejemplo, parece aludir al realismo mágico (nunca sabremos con cuánta seriedad) al referir en una entrevista -entre otros sucesos "típicos" del continentela historia de unos pescadores argentinos que sacan en sus redes jirafas, leones y elefantes que una tempestad había arrancado el día anterior de un circo en Comodoro Rivadavia. ${ }^{26}$

No hay verdadera relación de continuidad entre esos tres momentos, y por consiguiente el realismo mágico carece la cohesión necesaria para podérsele considerar como movimiento literario o crítico. El tercer momento no está directamente vinculado con el segundo, ya que Flores evidentemente desconoce en 1955 los pronunciamientos de Carpentier, Uslar Pietri y Portuondo; ni con el primero, ya que Flores y sus seguidores hacen caso omiso de las teorías de Roh o tienen una relación muy

24 Una de las categorías de Todorov ("le menveilleux") es precisamente aquella en que los personas no reaccionan de manera singular ante los acontecimientos: "Dans le cas du merveilleux, les éléments surnaturels ne provoquent aucune réaction particulière ni chez les personnages, ni chez le lecteur implicite. $\mathrm{Ce}$ n'est pas une attitude envers les événements rapportés qui caractérise le merveilleux, mais la nature même de ces événements" (op. cit., p. 59). Los ejemplos europeos son numerosos.

25 Valbuena Briones, "Una cala en el realismo mágico", op. cit.

26 Armando Durán, "Conversaciones con Gabriel García Márquez", Revista Nacional de Cultura (Caracas), 39 (1968), p. 31. 
lejana $y$ de trasmano con ellas, y pasan por alto, o niegan sin mostrat gran familiaridad con él, al surrealismo. Nadie, además, parece haberse percatado de la existencia de "El arte narrativo y la magia", ni haber considerado seriamente los problemas de la literatura fantástica que Borges expone alli y en todas sus obras. ${ }^{27}$ La continuidad o la cohesión no hay que buscarla en una secuencia histórica, pues ésta no existe, sino en ciertas coordenadas de pensamiento que subyacen a toda manifestación del realismo mágico como programa para la literatura hispanoamericana o como intento de explicar la literatura no-realista en la Hispanoamérica del siglo xx. Sólo haciendo un análisis detallado de este denominador común en sus varias funciones podremos comprender los prolegómenos de las teorias de Carpentier.

Hay dos vertientes del realismo mágico, a veces distinguibles por las dos rúbricas mencionadas. La primera, realismo mágico, que surge del libro de Roh, es la fenomenológica; la segunda, lo real maravilloso, de ascendencia surrealista, la ontológica. Es evidente que en la mayoría de las declaraciones recientes de la crítica, ambas aparecen confundidas bajo el mismo rótulo, pero estimo que vale la pena diferenciarlas.

Roh basa su ya olvidado libro en una de esas oposiciones binarias que con frecuencia se desprenden de la crítica histótica como explicación total de la trayectoria del arte en occidente (las más notorias son clasicismo-barroco, y romanticismo-clasicismo). En Roh la oposición consta de los siguientes polos: el impresionismo, que respeta el mundo real y reproduce fielmente sus formas; y el expresionismo, en el que las formas del mundo real son sometidas a las categorías del espíritu. En el primero, el objeto se impone al observador, al artista; en el segundo, el artista impone su propia subjetividad al objeto observado. Toda la historia del arte consiste para Roh en un movimiento pendular entre esas dos tendencias. Pero al llegar al postexpresionismo, que es el período que a Roh le interesa y que denomina mágico-realista, la dialéctica antes operante resulta en una síntesis. ${ }^{28} \mathrm{La}$ magia reside para Roh en el

27 Discusión (Buenos Aires: Emecé, 1966), pp. 81-92 (todas las citas en el texto remiten a esa edición). Para una introducción a los problemas que suscita ese ensayo, particularmente en su relación con el estructuralismo, ver: Emir Rodríguez Monegal, "Borges and La Nouvelle Critique", Diacritics, 2 (1972), pp. 27-40, y mi "With Borges in Macondo", Diacritics, 2 (1972), pp. 57-60.

28 "Para el impresionismo, el hecho de que el mundo constase de objetos era un hecho 'evidente', que no merecía mayor atención; el encanto de la pintura consistía, pues, propiamente, en dar el máximo valor y significación al tejido cromático, flotando en el aire. El expresionismo consideró también como harto 'evidente' la existencia de los objetos, y buscó su sentido en los ritmos poderosos, 
asombro ante la percepción del objeto simultáneamente en su devenir y sustraído de él: "en el postexpresionismo se nos ofrece el milagro de que las vibraciones de las moléculas -eterna movilidad-, de que el constante aparecer y desaparecer de lo existente, segregue, sin embargo, objetos permanentes. Este milagro de una aparente persistencia y duración, en medio del general devenir, de la universal disolución, es lo que el postexpresionismo quiere admirar y destacar". ${ }^{29}$ La visión franciscana del mundo que Roh le atribuye al postexpresionismo recuerda más la poesía de Jorge Guillén que la narrativa fantástica:

El balcón, los cristales
Unos libros, la mesa
¿Nada más esto? Sí,
Maravillas concretas.
Material jubiloso
Convierte en superficie
Manifiesta a sus átomos
Tristes, siempre invisibles. ${ }^{30}$

La minuciosa descripción de lo real para minar la familiaridad de la percepción habitual es característica de la estética de principios de siglo, desde un Azorín hasta los formalistas rusos, quienes sostenían, por ejemplo, que la metáfora chocante del poeta futurista forzaba al lector a percibir con mayor nitidez los objetos dispares que ésta aproximaba. ${ }^{31}$ Lo que varía en todos estos casos es el acto de percepción, que al asumir una pers-

violentos, de las formas, vasos en que el espiritu del hombre (sea artista u hombre de acción) puede verter todo cuanto existe. Pero la pintura más reciente pretende llegar a una base más general y honda, sin la cual no hubieran podido actuar los dos afanes anteriores, que, sin devoción por el objeto, aceptaban como 'evidente' la existencia de ese mundo objetivo que el arte ha de plasmar y conformar. Al hacerse aqui 'problema' por vez primera lo que antes fuera aceptado como evidente, penetramos en una capa mucho más honda, por insuficientes que nos parezcan los resultados en detalle. Esa sosegada admiración ante la magia del ser, ante el descubrimiento de que las cosas tienen ya sus figuras propias, significa que se ha reconquistado - aunque por modos nuevos- el suelo sobre el cual pueden arraigar las concepciones más diversas del universo". Revista dé Occidente, 5 (1927), p. 281. Me ha sido imposible conseguir ejemplar de la traducción al castellano del libro de Roh. Las páginas aquí citadas de una entrega aparecida en la Revista de Occidente corresponden a las páginas 29-30 de Nach-Expressionismus (Magiscber-Realismus). (Leipzig: Klinkhardt \& Biermann, 1925).

29 Ibid., p. 281. Nacb-Expressionismus, p. 33.

30 Cántico, $1^{\mathrm{a}}$ ed. completa (Buenos Aires: Sudamericana, 1950), p. 21.

31 "L'art est compris comme un moyen de détruire l'automatisme perceptif, l'image ne cherche pas à nous faciliter la compréhension de son sens, mais elle cherche à créer une perception particulière de l'objet, la création de sa vision et non de sa reconnaisance". Théorie de la littérature. Textes des Formalistes Russes. Présentés et țaduits par Tzvetan Todorov (París: Editions du Seuil, 1965), p. 45. 
pectiva inusitada proyecta sobre la realidad un asombro o una devocación que hacen del gesto y del objeto un milagro - las "maravillas concretas" de que habla Guillén y la "magia del ser" a que a veces apela Roh. Es el roce de los dos elementos, de la subjetividad y de lo real, lo que genera la alquimia, pero lo real, según Roh, permanece inmutable.

Aunque se le debe a Roh el haber acuñado el término realismo mágico, así como el haber logrado aislar una característica saliente de la vanguardia, la estética de lo minúsculo, su versión del concepto no es la que mayor fortuna tiene entre los escritores del nuevo Mundo -a pesar de que su libro fue leído ávidamente en Hispanoamérica en la traducción diseminada por la Revista de Occidente. Carpentier recuerda el libro de Roh en su pronunciamiento de 1948 únicamente para crear el oxímoron "real maravilloso" (lo maravilloso venía de los surrealistas), y en algunos detalles marginales. En el artículo de Uslar Pietri, la huella de Roh, aparte del uso del término, es aperias visible.

En una reseña publicada a raíz de la aparición en castellano del libro de Roh, Antonio Espina hace algunas observaciones que permiten explicar por qué no tuvo más éxito entre los escritores hispanoamericanos la teoría del alemán (dejando aparte el simple hecho de que sus teorías se referían a las artes plásticas, específicamente a la pintura). La estética que define Roh, observa Espina, es "una estética media, en suma, situada resueltamente, entre el sensualismo informe y el esquematismo superestructurado. Se trata de un realismo idealista [...] Mágico en cuanto crea un nuevo espiritu que tiene su forma en lo sobrenatural, en lo superreal. Y se llama precisamente mágico para evitar que salga nunca de la esfera neutra de la idealidad y el subjetivismo y caiga y pueda confundirse con el realismo religioso." 32 El propio Roh, recordando años después la génesis del término, insiste sobre este punto: "In an article written in 1924 I coined the phrase Magischer Realismus (magic realism) -magic of course not in the religious sense of Ethnology." 33 La falla de Roh estriba en querer surtraer del fenómeno que describe la vertiente trascendentalista y religiosa que posee, para evitar que ésta contamine la antisepsia fenomenológica y formalista de su teoría. Pero el poema de Guillén citado más arriba se intitula "Más allá", y la propia fraseología de Roh habla de devociones y milagros. Las teorías de Roh no tienen mayor impacto sobre el escritor hispanoamericano porque el milagro que éste persigue no es neutro, sino que aspira mediante él a fundirse en un

32 Revista de Occidente, 5 (1927), pp. 112-13.

33 German Art in the Twentietb Century (New York Graphic Society Ltd.: Greenwich, Conn., 1968), pp. 112-13. 
orden trascendente - sólo que ese orden no es ya el provisto por la tradición occidental. Roh tiene que acudir a ese neutralismo porque no puede concebir otro orden trascendente que el que le brinda la tradición europea, y por ello acude a la fenomenologia; es decir, a las diferencias en el acto de percepción, no a las diferencias en el observador -de ahí que su realismo mágico sea tambiẻn denominado Neue Sacblicbkeit, nueva objetividad. De ahi también que utilice el término magia, para cubrir con un velo de neutralidad el aspecto trascendente, y dejar intacta la separación, el dualismo, entre el mundo observado y el artista. Porque, a pesar de la distinción que Roh quiere mantener entre su magia y la de la etnología, lo cierto es que magia es el término usado por los pioneros de la etnología a finales del siglo xIx y principios del xx para describir creencias religiosas y rituales de gentes primitivas en los que el investigador no creía. El término magia es un instrumento que sirve para distanciar al observador de lo sobrenatural que describe desde una perspectiva europea, y para la comprensión de europeos:

For nineteenth-century thinkers like Tylor (1871), McLennan (1865-1876), Spencer (1876-1896), and Lang (1901), the question of greatest interest was the origins of magic as related to the origins of religion. Their works were attempts to understand how early man was led in the direction of superstition by faulty observation and reasoning. This line of inquiry led to Lévy-Bruhl's famous work on primitive mentality (1910). Frazer (1890) was also working on evolutionary premises. [...] Frazer regarded magic as an earlier, primitive form of both religion and science. He observed rightly that primitive practice is often based on excellent observation of natural phenomena and involves a theory of causality. He therefore felt that there was a basic similarity between magic and science. The only difference was that for a variety of reasons the mistaken assumptions and erroneous conclusions of magic were veiled from the observer and did not shake bis beliefs (el subrayado es mío). ${ }^{34}$

El escritor hispanoamericano prefiere instalarse del lado de allá de esa estética media o fronteriza que describe Roh; de lado del salvaje, del cre-

34 Nur Yalman, "Magic", International Encyclopedia of the Social Sciences (Nieva York: Mac Millan, 1968), v. 8, p. 521. Para una detallada introducción bibliográfico-crítica de estudios sobre la magia, ver el primer capítulo de la obra de Marcel Mauss, "Esquísse d'une théorie générale de la magie", en Sociologie et antbropologie, int. Claude Lévi-Strauss (París: Presses Universitaires de France, 1969), pp. 3-9. La introducción crítica de Lévi-Strauss a este volumen es fundamental para una comprensión teórica del tema en términos modernos. 
yente, no en ese punto ambiguo donde el milagro se justifica por un acto de percepción reflexivo, en que la conciencia de la distancia entre el observador y lo observado, entre el sujeto y ese otro exótico, genera la extraneza y el asombro. En el prólogo de El reino de este mundo Carpentier afirma que "Para empezar, la sensación de lo maravilloso presupone una fe" (p. 11). La tendencia hacia esa fe, hacia lo trascendente que Roh intenta esquivar con el adjetivo mágico, se encuentra en la otra vertiente de pensamiento en que se apoya el realismo mágico, la ontológica, que es la que mayor fortuna ha gozado en Hispanoamérica.

Es notorio que el Modernismo europeo (es decir, lo que vino a ser la vanguardia), desde la época que Shattuck ha llamado "banquet years" constituye la búsqueda de una visión del mundo diferente u opuesta a la de la cultura occidental. ${ }^{35}$ Las manifestaciones de esa búsqueda son bien conocidas: el Negrismo, el interés por la subconciencia, la reacción contra el positivismo y el neo-kantismo, el auge del vitalismo bergsoniano, el irracionalismo tanto en filosofía (piénsese en Unamuno, por ejemplo) como en las artes, el redescubrimiento de Nietzsche, etc. Todas esas manifestaciones van acompañadas de un fenómeno muy significativo -el inusitado desarrollo de la etnología, que tiende a descentrar el pensamiento, la historia y la estética de Europa, al describir por vez primera con lujo de detalles la riqueza de culturas primitivas hasta entonces vistas como bárbaras (las mismas obras de Tylor, McLennan, Spencer, Lang, Lévy-Bruhl y Frazer, antes mencionadas, además de la del africanista León Frobenius). Todas esas tendencias tuvieron una difusión en extremo amplia en el mundo de habla española a partir de 1923, gracias a la Revista de Occidente, y a la labor de su director José Ortega y Gasset. ${ }^{36}$ En Las Atlántidas, en 1924, Ortega hacía las siguientes observaciones y vaticinios:

35 "Modernism coincides in significant fashion with primitivism. Gauguin's 'flight' to Tahiti en 1891 may not have produced his best work but it reveals the integrity of his desire for another vision. Anarchism itself can be seen as a form of political primitivism trying to return to an earlier stage of social evolution. What one can overlook most easily in all this demonstration is its stubbotn purpose to change the aspect of both life and art". T'be Banquet Years. T'be Origins of the Avant Garde in France - 1885 to World IVar I, revised edition (Nueva York: Vintage Books, 1968), p. 24.

36 Aunque escasamente estudiada, la influencia de la Revista de Occidente sobre las vanguardias hispanoamericanas fue decisiva (el único estudio introductorio se encuentra en Zea, Esquema para una bistoria, op. cit.). El propio Carpentier alude a la Revista de Occidente en varios artículos suyos de los años cincuenta, pero en especial en uno escrito a raíz de la muette de Ortega, del que cito un fragmento: "La Revista de Occidente, fue, durante años, nuestro faro y guía. Estableció un nuevo orden de relaciones intelectuales entre España y América Latina, relaciones de las que surgieron empresas tan fecundas como la Institución 
en los últimos veinticinco años se ha ampliado gigantescamente el horizonte de la historia. Se ha ampliado tanto que la vieja pupila europea, habituada a la circunferencia de su horizonte tradicional de que ella era centro, no acierta ahora a encajar en una única perspectiva los enormes territorios súbitamente añadidos. Si hasta el presente la "historia universal" había padecido un exceso de concentración en un punto de gravitación único, hacia el cual se hacían converger todos los procesos de la existencia humana -el punto de vista europeo-, durante una generación, cuando menos, se elaborará una historia universal policéntrica y el horizonte total se obtendrá por mera yuxtaposición de horizontes parciales, con radios heterogéneos que hacinados formarán un panorama de los destinos humanos bastante parecido a un cuadro cubista. ${ }^{37}$

En Europa, el impacto de las investigaciones etnológicas fue enorme. El artista europeo quiere ser otro, quiere ver el mundo desde otro modo de ser. Los hispanoamericanos, que desde el Romanticismo - según vimos en Hentiquez Uteña- quetían afirmar la diferencia y autonomía de su cultura con respecto a la europea, se suman inmediatamente a esta tendencia de la vanguatdia (Asturias redacta en Paris sus Leyendas de Guatemala, que publicaría en 1930, y que se desprenden de sus estudios de etnologia con Georges Raynaud). Mientras que en pintura y escultura se rompe con lo que se considera el legado europeo mediante la estilización y. la reducción a formas y colores primarios, en la literatura narrativa el descentramiento ocurre en el plano de la causalidad - la relación causaefecto por la cual se articula el argumento, y que desde Aristóteles había sido la piedra angular de todo proyecto narrativo. Conviene detenerse un momento sobre esto, y observar cómo se presenta el problema en Borges.

En "El arte narrativo y la magia" Borges propone que todo proceso

Hispano-Cubana de Cultura, que presidía Don Fernando Ortiz. Sus páginas eran ventanas abiertas sobre todo un pensamiento, ayer ignorado de quienes no fuesen lectores especializados, que se nos mostraba por primera vez. ¿Cuántos autores alemanes, ingleses, franceses; cuántos filósofos, cuántos historiadores de arte, no conocimos gracias a la Revista de Occidente, cuyas entregas nos revelaban, además, los nombres de Lord Dunsany, de Georg Kaiser, de Franz Kafka, del Cocteau de Orfeo - toda una dramática, toda una cuentística-, sin olvidar, para quienes se interesaban en los problemas de la música, los primeros ensayos de Adolfo Salazar?" "Ortega y Gasset", Letra y Solfa, El Nacional (Caracas), 20 de octubre de 1955 (cito por copia xérox de este artículo donde no aparece el número de la página).

37 Las Atlántidas (Madrid: Revista de Occidente, 1924), p. 31. Nótese el evidente anti-hegelianismo de Ortega en esta cita. Ortega era por esos años spengleriano. Para más precisiones sobre este tema, consúltese: Ciriaco Morón Arroyo, El sistema de Ortega y Gasset (Madrid: Ediciones Alcalá, 1969), esp. pp. 299-303. 
narrativo es mágico, y alude al conocido libro de Frazer, The Golden Bough: "Ese procedimiento o ambición de los antiguos hombres ha sido sujetado por Frazer a una conveniente ley general, la de la simpatía, que postula un vínculo inevitable entre cosas distantes, ya porque su figura es igual -magia imitativa, homeopática - ya por el hecho de una cercanía anterior -magia contagiosa. Ilustración de la segunda era el ungüento de Kenelm Digby, que se aplicaba no a la vendada herida, sino al acero delincuente que la infirió - mientras aquélla, sin el rigor de bárbaras curaciones iba cicatrizando." ${ }^{38} \mathrm{La}$ ficción narrativa, afirma Borges, se rige por una ley análoga: "Esa peligrosa armonía, esa frenética y precisa causalidad, manda en la novela también. [...] Ese recelo de que un hecho temible pueda ser atraído por su mención, es impertinente o inútil en el asiático desorden del mundo real, no así en una novela, que debe ser un juego preciso de vigilancias, ecos y afinidades" (p. 89). Borges no niega la causalidad en la narrativa, ni ofrece otra causalidad extravagante $o$ insólita, como harán muchos escritores europeos e hispanoamericanos en pugna contra lo que consideran moldes de arte y pensamiento occidentales, sino que destaca el parentesco de ésta con la magia, con el proceso de la cura homeopática del primitivo. La causalidad en la ficción no es determinada por una ley natural ni por el reflejo del orden del mundo físico, sino por la ley de simpatia o atracción que es arbitraria, ya que para Borges el mundo real es el que carece de concierto: "He distinguido dos procesos causales: el natural, que es el resultado de infinitas operaciones; el mágico, donde profetizan los pormenores, lúcido y limitado. En la novela, pienso que la única honradez está con el segundo" (p. 91).

La Poética de Aristóteles formulaba, como es sabido, una teleología narrativa análoga a la de Borges: el argumento es un todo coherente, con principio, medio y fin, en el que nada puede preceder al principio, ni nada exceder al final, y en el que todo incidente surge de los anteriores por una ley de necesidad. No es puramente estética esà disposición, sin embargo. La clave de ese principio fundamental de la Poética, que rige por siglos en la literatura, es la base misma de la filosofía aristotélica -el argüumento cosmológico. Así como el cosmos está ordenado en su movimiento por una serie de actos-potencias que remiten al inmóvil primer motor - a ese indiferente e hierático Dios-, la trama de una obra,

38 "El arte narrativo y la magia", op. cit., p. 88. Las citas indicadas en el texto provienen de la edición mencionada en la nota 27 , supra. No deja de ser curioso que en la Antología de la literatura fantástica de Borges, Silvina Ocampo y Adolfo Bioy Casares, se incluya a Frazer (Buenos Aires: Sudamericana, 1971), pp. 186-87. 
que es imitación de acciones, debe reflejar el mismo principio de composición. ${ }^{39}$ De una manera u otra, variando según el modo de representar ese reflejo, toda versión del realismo supone esta relación especular ẹntre la realidad y el arte - contra ella se dirige toda la vanguardia. Pero, en vez de quebrar el espejo para crear una serie de imágenes discontinuas, Borges en cambio lo pule para que muestre con mayor nitidez una imagen completa y ordenada, pero que no es reflejo de un orden real, sino completa en sí. La magia que define Borges en su ensayo no depende, como en Roh, de la observación privilegiada de un mundo concordante y organizado hasta sus últimas e ínfimas minucias y partículas, y por el que sentimos asombro y devoción. Las maravillas de Borges no son concretas y estáticas, sino funciones dinámicas del ser, del ente que emerge en sus ficciones; especie de pequeño Dios aristotélico que se piensa a sí mismo. El término magia ya no neutraliza el trascendentalismo implícito a esa visión, sino que subraya, no sin cierta ironía muy propia de Borges, su carácter religioso. Aceptamos la causalidad en el orden narrativo sin reparos, con fe ciega, de la misma manera que el primitivo acepta la eficacia de la cura homeopática. En ambos se salta por sobre el vacío del caos y la arbitrariedad mediante un acto de fe. De ahí que para Borges la teología sea una forma, tal vez la más elevada $a_{2}$ de la literatura fantástica, porque en ésta se supone la existencia de un principio ordenador que da coherencia al universo y concierto a sus fenómenos:

Yo he compilado alguna vez una antología de la literatura fantástica. Admito que esa obra es de las poquísimas que un segundo Noé debería salvar de un segundo diluvio, pero delato la culpable omisión de los insospechados y mayores maestros del género: Parménides, Platón, Juan Escoto Erígena, Alberto Magno, Spinoza, Leibniz, Kant, Francis Bradley. En efecto, ¿qué son los prodigios de Wells o de Edgar Allan Poe -una flor que nos llega del por-

39 Georg Lukács ha notado ese aspecto "mágico" de la teoría aristotélica: "Aristóteles determina la fábula como una composición artística acertada de los acontecimientos. La fábula es, incluso en su forma más primitiva, más que una mera sucesión; precisamente la finalidad mágica aspira a una ordenación teleológica de las partes en el sentido de una finalidad determinada y tepresentada por lo cual ocurre no sólo que, dentro de ciettos límites, la sucesión muta en génesis, en vinculación causal (aunque la causalidad sea fantasmagórica), sino también que determinadas exacerbaciones, pausas, retrocesos, etc., se ordenan unos con otros y encajan en el sentido de la finalidad y se desarrollan unos de otros. Una categoría como la de la fábula, tan central luego para una literatura posterior, surge así con necesidad temática de las finalidades mágicas de las formaciones miméticas más primitivas". Estética I. La peculiaridad de lo estético, v. 2 (Barcelona-México: Ediciones Grijalbo, 1966), p. 54. 
venir, un muerto sometido a la hipnosis - confrontados con la invención de Dios, con la teoría laboriosa de un ser que de algún modo es tres y que solitariamente perdura fuera del tiempo? ¿Qué es la piedra bezoar ante la armonía pre-establecida, quién es el unicomio ante la Trinidad, quién es Lucio Apuleyo ante los multiplicadores de Buddhas del Gran Vehículo, qué son todas las noches de Shahrazad junto a un argumento de Berkeley? He venerado la gradual invención de Dios; también el Infierno y el Cielo (una remuneración inmortal, un castigo inmortal) son admirables y curiosos designios de la imaginación de los hombres. ${ }^{40}$

La magia, la literatura fantástica y la teología son en el universo borgiano reflejos de una misma empresa ficticia. Sólo que para Borges los creadores de orden en la trama del universo de la escritura no son seres perfectos, sino criaturas de dudosa motivación. En "La muerte y la brújula" el criminal Scharlach es quien ha urdido el falso orden que atrapa a su propio reflejo, ese otro hacedor, el vagamente pomposo detective Lönnrot; en "El jardín de los senderos que se bifurcan" el orden lo crea el espía chino, quien con la muerte de Stephen Albert logra comunicar al enemigo el fatídico mensaje; en "El milagro secreto" nunca sabemos si una divinidad superior ha concedido al condenado escritor un año para terminar de componer su drama, o si el propio dramaturgo vislumbra todo el argumento de la misma en el segundo antes de morir. En la fraudulenta teología borgiana -especie de teúrgia_ ${ }^{41}$ los dioses menores son el detective, el criminal, el espía, y por supuesto, el escritor. Todos afirman y niegan a la vez la posibilidad de que exista una deidad superior, tal vez más perfecta y poderosa, pero quizás más perversa que ellos; la afirman en el arduo trabajo de construcción, la niegan en el hecho de que todos mueren en el momento de contemplar la totalidad de ese orden que traman en su laberíntica y tenue complejidad. Como en la tragedia,

40 Discusión, op. cit., pp. 172-73.

41 José Ferrater Mora, en su Diccionario de Filosofía (Buenos Aires: Sudamericana, 1965), define la teúrgia como "la creencia en la posibilidad de que los dioses o demonios influyan sobre los fenómenos naturales, así como el conjunto de prácticas destinadas a hacer que tal influencia se ejerza en sentido favorable para el hombre que la requiera". v. 2, p. 783. San Agustín, quien condena la teúrgia como una forma más de la magia o goecia, dice lo siguiente: "Fiebant autem simplici fide atque fiducia pietatis, non incantationibus nefariae curiositatis arte compositis, quam vel magiam, vel detestabiliore nomine goetiam, vel honorabiliore theurgiam vocant qui quasi conantur ista discernere, et illicitis artibus deditos alios damnabiles, quos maleficos vulgus appellat (hos enim ad goetiam pertinere dicunt) alios autem laudabiles videri volunt, quibus theurgiam deputant; cum sint utrique ritibus fallacibus daemonum obstricti sub nominibus angelorum". De civitate Dei, $\mathrm{X}, 9,1$. 
el momento anagnórisis es el de la muerte; la reconstitución, la conjunción final precede la disyunción definitiva, el cruce irrevocable a la otra orilla - el rey muerto en su laberinto.

A pesar de tener una clara relación con el auge de la etnología, el ensayo (y la obra) de Borges no conduce al policentrismo que vaticinó Ortega, sino a una ausencia de centro. Si la magia del primitivo es homóloga en su funcionamiento al proceso narrativo de la cultura occidental, lo que se supone es una estructura de base que subyace a todas las culturas, no una diferencia entre ellas; esto lleva igualmente implícito que el orden visible de la cultura europea enmascata otro, en el que no se diferencia, ni es superior a otras culturas; en Borges no sólo no hay primitivismo sino que se niega la posibilidad del primitivismo. En este aspecto el ensayo de Borges se emparenta más con el surrealismo que con los primeros estudios etnológicos. El surrealismo, apoyándose en Freud, proponía la existencia de un orden subconsciente que podía aflorar, como es sabido, en el sueño o en el correr de la escritura automática. ${ }^{42}$ Es decir, los surrealistas sostenían que la libre asociación no era libre, de la misma manera en que Borges proclama que la causalidad en la narrativa, aunque arbitraria con respecto al mundo real, es rigurosamente sistemática en sí. Desde esta perspectiva no hay ruptura posible por donde los elementos que componen el relato pueda ser cuestionada: en Borges porque para él toda literatura es fantástica, para los surrealistas porque el nuevo orden que se revela es uno con el cosmos - los vasos son todos comunicantes. En Borges y el surrealismo lo que se sugiere es la existencia de una especie de superlógica, o supralógica universal. La magia, el sueño, la alucinación, el orden narrativo, no son propiedad exclusiva de esta o aquella

42 La relación entre el surrealismo y Freud no es tan simple, por supuesto, aunque el método de la libre asociación sí fue incorporado del sicoanálisis. La diferencia fundamental entre Breton y Freud resulta del materialismo del primero, que no le permite aceptar la separación que establecia el sicoanálisis entre el "trabajo de los sueños" y la realidad: "As a consistent materialist, Breton tries to show that space, time and the principle of causality are identical in dreams to what they are in reality, i. e. laws or objective forms of existence, and not pro. perties of our mind". Jean-Pierre Morel, "Breton and Freud", Diacritics, 2 (1972), p. 19. Jean Starobinski habla de un "materialismo mágico": "A qui parle dans l'écriture automatique, nous dit Breton, ce n'est pas un interlocuteur défunt ou lointain qui se servirait de notre main comme d'un instrument docile: c'est la spontanéité de la pensée véritable, pensée qui n'est pas l'apanage du génie, mais le bien commun de tous les hommes [...] En même temps, Breton nous assure que cette parole pourrait articuler le même message en chaque homme: c'est un flux neutre, où la conscience se fait impersonelle pour acueillir la voix confuse et merveilleuse de l'univers. Breton en vient ainsi à formuler ses propres hypothèses métaphysiques dans le sens d'un matérialisme magique". "Freud, Breton, Myers", L'Arc, 34 (1968), p. 95. Starobinski demuestra en este trabajo el trasfondo de parasicología ocultista del siglo xIX presente en el pensamiento de Breton. 
cultura, sino manifestaciones superficialmente disímiles, pero homólogas, del ser: Breton y Borges no proponen sino una suerte de onto-teología.

Hay que apresurarse a añadir, sin embargo, que las diferencias entre Borges y el surrealismo son significativas, y lo apartan definitivamente de Carpentiet. El surrealismo, como ha explicado Octavio Paz, aspiraba i una especie de monismo que borrara la separación entre el hombre y el mundo:

E1 surrealismo se presenta como una radical tentativa por suprimir el duelo entre sujeto y objeto, forma que asume para nosotros lo que llamamos realidad. Para los antiguos el mundo existía con la misma plenitud que la conciencia y sus relaciones eran claras y naturales. Para nosotros su existencia asume la forma de una disputa encarnizada: por una parte, el mundo se evapora y se convierte en imagen de la conciencia; por la otra, la conciencia es un reflejo del mundo. La empresa surrealista es un ataque contra el mundo moderno porque pretende suprimir la contienda entre sujeto y objeto. Heredero del romanticismo, se propone llevar a cabo esa tarea que Novalis asignaba a "la lógica superior": destruir la "vieja antinomia" que nos desgarra. Los románticos niegan la realidad -cáscara fantasmal de un mundo ayer henchido de vida- en provecho del sujeto. No hay yo, no hay creador, sino una suerte de fuerza poética que sopla donde quiere y produce imágenes gratuitas e inexplicables. ${ }^{43}$

En Borges, cuyas raíces filosóficas se hunden en la transparencia del idealismo, persiste la dualidad entre el liso orden del espíritu y el turbio y accidentado universo. Lo pertinente, no obstante, es que tanto Borges como el surrealismo persiguen formas definitorias del hombre en un sentido universal, en contra de una visión centrada de la historia de orientación hegeliana, o policántrica de orientación spengleriana.

No asi en Carpentier y la mayoría de los artistas e intelectuales hispanoameticanos, que optan por el policentrismo anunciado por Ortega - policentrismo que era apoyado por libros como La decadencia de Occidente con persuasivas teorías-, dando así una versión distinta del realismo mágico, aunque desde la misma vertiente ontológica.

A pesar de su documentable fascinación por el surrealismo en un momento de su vida, Carpentier nunca se deja seducir del todo por Breton

13 El arco y la lira, 2da ed. (México: Fondo de Cultura Económica, 1967), p. 171. Véase la nota anterior. 
y sus teorías; por el contrario, Carpentier se afana por aislar en su concepto de lo maravilloso algo que sea exclusivamente hispanoamericano. ${ }^{44}$ Si Borges y Breton suponen un modo de ser en que el salvaje y el hombre civilizado se despojan de sus diferencias, Carpentier persigue lo maravilloso en las capas soterradas del ser hispanoamericano, donde todavía percuten tambores africanos y rigen hoscos amuletos indígenas; profundidades donde lo europeo es un vago recuerdo del porvenir: " $Y$ es que, por la virginidad del paisaje, por la formación, por la ontología, por la presencia fáustica del indio y del negro, por la Revelación que constituyó su reciente descubrimiento, por los fecundos mestizajes que propició, América está muy lejos de haber agotado su caudal de mitologías" (pp. 1516). Aparte de los ataques contra determinados surrealistas, resabio de pugnas de los años treinta, ${ }^{45}$ el ensayo de Carpentier se resume a que lo maravilloso existe todavía en América, ${ }^{46}$ y que éste se revela a los que

14 En 1928, Carpentier escribe un elogioso y entusiasta artículo sobre Breton y el surrealismo (Social, diciembre de 1928 , pp. 38, 74, 75, 76), pero ya en 1930 participa con su amigo Robert Desnos y otros en un violento ataque contra el padre del surrealismo, y contribuye una nota (hasta ahora olvidada) al libelo que publica el grupo disidente, intitulado Un cadavre:

"Témoignage"

'La valeur subversive de l'oeuvre

d'Eluard'.

André Breton

J'ai vu une seule fois André Breton (au cours de juillet 1928). Je lui ai dit que le Surréalisme était connu en Amérique Latine par les poèmes de Paul Eluard. Il m'a répondu que si les choses se passaient ainsi le Sutréalisme était 'foutu' (Il répéta plusieurs fois ce mot). Il m'a déclaré de plus que pour lui, les poèmes d'Eluard étaient 'l'opposé de la poésie', et qu'il n'y comprenait absolument rien.

Alejo Carpentier-

(Le poète mexicain Jorge Cuesta était présent à cet entretien).

18 Rodríguez Monegal, "Lo real y lo maravilloso..." op. cit., y Müller-Bergh, "Corrientes vanguardistas y surrealismo en la obra de Alejo Carpentier", Revista Hispánica Moderna, 35 (1969), 323-340, han estudiado en sendos artículos los pormenores de la ruptura de Carpentier con el grupo surrealista. Rodríguez Monegal tiene razón al hablar de las tensiones de tipo político que surgen en el seno del grupo surrealista; sin embargo, a mi modo de ver, la razón principal por la que Carpentier no se suma nunca del todo al movimiento es que éste chocaba con la ideología de base spengleriana que habia asimilado a través de la Revista de Occidente desde principios de la década de los veinte, y que sigue esgrimiendo durante la de los cuarenta. Ambos trabajos han sido recogidos en Asedios a Carpentier. Once ensayos criticos sobre el novelista cubano, ed. Klaus Müller-Bergh (Santiago de Chile: Editorial Universitaria, 1972).

46 A cada paso [habla Carpentier de su viaje a Haití en 1943 ] hallaba lo real maravilloso. Pero pensaba, además, que esa presencia y vigencia de lo real maravilloso no era privilegio de Haití, sino patrimonio de la América entera, donde todavía no se ha terminado de establecer, por ejemplo, un recuento de cosmogonias" (p. 13). 
creen en él; no por un acto reflexivo o autoconsciente. Inclusive en los ataques contra el surrealismo el ensayo de Carpentier está basado on Spengler, y es sólo acudiendo a La decadencia de Occidente que puede comprenderse lo que Carpentier entiende por maravilloso, y cómo define esa fe que lo sustenta.

Como es sabido, Spengler proponía en su tan difundido libro que las culturas eran organismos que sufrían evoluciones análogas hasta desaparecer (el universo como historia). Esta idea, la más difundida y vulgarizada del filósofo alemán, es pertinente aquí; sin embargo, lo que más nos interesa es que, a diferencia y en contra de Hegel, Spengler mantenía que la decadencia de una cultura empezaba a manifestarse cuando surgía la reflexividad:

Aparecen, empero, los primeros síntomas de un alma declinante cuando despierta un sentimiento de extrañeza ante esas formas [de la cultura], el sentimiento de un peso que anula la libertad creadora, la obligación de examinar y criticar con el intelecto la realidad actual, para aplicarle conscientemente, la tiranía de una reflexión fatal para todo elemento misteriosamente creador. El que siente sus miembros es porque está enfermo. Construir una religión ametafísica y rebelarse contra los cultos y dogmas; oponer un derecho natural a los derechos históricos; inventar estilos artísticos por no poder ya soportar y conminar el estilo; concebir el Estado como un "orden social" que puede cambiarse $[. .$.$] todo eso demuestra$ que algo se ha destruido para siempre.47

Para Spengler, como luego para Carpentier y tantos otros hispanoamericanos que sucumbieron bajo su influencia, el Nuevo Mundo se encontraisa en un momento de su ciclo cultural - momento de fe- anterior al de la reflexividad; mientras que Europa se sentía extraña ante las formas de su propia cultura y buscaba en leyes y códigos de pretensiones universalistas, como el surrealismo, el misterio de la creación irremediablemente perdido. La oposición entre lo europeo y lo primitivo que establecia Spengler $-\mathrm{y}$ su correlato: incredulidad/fe- es la misma que el filósofo alemán erigía entre civilización y cultura: "La esencia de toda cultura es religión, la esencia de toda civilizaciớn es irreligión $[\ldots]$ irre-

47 La decadencia de Occidente (Madrid: Espasa Calpe, 1923), v. I, 442. La vigencia, aun pasada la mitad de los cuarenta, del pensamiento spengleriano en Carpentier se puede corroborar, además de en este prólogo, en su artículo "Giovanni Papini la emprende con América", El Nacional (Caracas), 1 de junio de 1947, p. 11 . 
ligiosas, inánimes, son pues, también esas emociones éticas universales que pertenecen al idioma de formas de las grandes urbes." 48 Son precisamente estos razonamientos los que utiliza. Carpentier para atacar el surrealismo; que según él se ha convertido en un "código de lo fantástico", y que se erige como una nueva ética (además de estética) universal, que se ha convertido en algo inánime, muerto. ${ }^{49}$

Fernando Alegría, en uno de los pocos trabajos analíticos sobre el realismo mágico, y uno de los primeros además dedicados a la obra de Carpentier, tuvo el gran acierto de notar el aspecto onto-teológico de lo propuesto por Carpentier en su prólogo a $E l$ reino de este mundo: "La magia de Carpentier y. Asturias puede ser genuina experiencia metafísica, es decir, compromiso personal no sólo en el reino de éste sino también del otro mundo." ${ }^{50}$ En efecto, lo maravilloso en Carpentier responde a

48 Ibid., p. 448. El vínculo preciso entre el hombre de cultura y el cosmos - su cultura, su paisaje- lo establece Spengler de la manera siguiente: "esa protoforma del mundo es innata, en cuanto que pertenece originariamente al alma de esa cultura, que se expresa en nuestra vida entera; pero también es adquirida, en cuanto que cada alma repite por sí ese mismo acto creador [...] La primera comprensión de la profundidad es como un sacimiento, nacimiento espiritual junto al corporal. Las culturas nacen así de su paisaje materno. $\mathrm{Y}$ ese nacimiento lo repite luego en su círculo cada alma individual. [...] Llamaremos en adelante símbolo primario de una cultura a su modo de sentir la extensión. El símbolo primario es la base de donde hay que derivar todo el lenguaje de formas que nos habla la realidad de cada cultura..." Ibid., p. 229. De este modo pretende saltar Spengler por sobre el problema del dualismo hombre-cosmos, y el de la reflexividad; la cultura se expresará a través de cada uno de sus individuos espontáneamente, aún en estado de vigilia, porque ésta es innata, y producto de una percepción común del paisaje circundante. El lenguaje de Carpentier en su prólogo es tan spengleriano en algunos casos que tal vez sea ocioso apuntarlo, por ejemplo: "Y tuvo que ser un pintor de América, el cubano Wifredo [sic] Lam, quien nos enseñara la magia de la vegetación tropical, la desenfrenada Creación de Formas de nuestra naturaleza..." (pp. 9-10).

49 "Pero a fuerza de querer suscitar lo maravilloso a todo trance, los taumaturgos se hacen burócratas. Invocando por medio de fórmulas consabidas que hacen de ciertas pinturas un monótono baratillo de relojes amelcochados, de maniquíes de costurera, de vagos monumentos fálicos, lo maravilloso se queda en paraguas o langosta o máquina de coser, o lo que sea, sobre una mesa de disección, en el interior de un cuatto triste, en un desierto de rocas. Pobreza imaginativa, decía Unamuno, es aprenderse códigos de memoria. Y hoy existen códigos de lo fantás. tico..." (p. 9). Ver en La decadencia de Occidente el capítulo IV, "Música y plástica", en particular las pp. 370-75, de las que copiamos el siguiente párrafo: "Recorriendo exposiciones, conciertos y teatros, ¿qué vemos? Industriosos artífices $\mathrm{y}$ necios tonitruantes que se dedican a aderezar para el mercado cosas harto conocidas ya por supérfluas e inútiles. IA qué nivel de dignidad interna y externa ha descendido lo que hoy llamamos arte y artistas! En cualquier asamblea general de accionistas o entre los ingenieros de una fábrica cualquieta hallaremos más inteligencia, más gusto, más carácter y aptitud que en toda la pintura y la música de la Europa actual" (p. 373). Spengler habla aquí de la ausencia en Europa de un arte necesario; Carpentier se hace eco de estas reflexiones, añadiendo que el arte de América responde siempre a necesidades, en "Lo necesario en literatura", El Nacional (Caracas) [Letra y Solfa], 20 de diciembre de 1953, p. 58.

50 "Carpentier: realismo mágico", op. cit. Salvo el trabajo de Rodríguez Mone- 
una presunta ontología, a una peculiar forma de ser del hispanoamericano que excluye la reflexividad para dar paso a la fe, y que le permite vivir inmerso en la cultura y sentir la historia como sino, no como un proceso causal analizable intelectual y racionalmente - Ti Noel al final de El reino de este mundo, estupefacto, anonadado por la creación de varios estados que se han ido implantando a su alrededor como nuevos órdenes sociales y políticos, destruyendo su mundo de mitos y de leyendas. Desde la perspectiva a que ese modo de ser aspira, la fantasía deja de ser incongruente con respecto al mundo real para convertirse ambos en un mundo cerrado y completo, esférico, sin fisuras ni desdoblamientos irónicos, que se percibe "en virtud de una exaltación del espíritu que lo conduce a un modo de "estado límite" (11).

En Borges, como se ha visto, se subraya el cariz religioso del proceso narrativo, que pide un principio trascendente que lo ordene, que postula un ente específico que lo elabore, pero la ironía siempre perceptible en su prosa deja aún inconexo y sin dios su mundo de rigurosos azares; además, vistos al trasluz de sus textos ese ente y ese dios se difuminan, se dispersan como el rayo al pasar por un prisma - los muchos y siempre elusivos Borges de su ficción (el "yo plural" del "Poema de los dones"), los "dioses menores" antes mencionados. Carpentier, por el contrario, aspira a fundamentar ese principio trascendente que pide la narrativa en la fe que le ofrece la cultura, la historia hispanoamericana; en el caudal de mitologías y creencias que él considera vigentes aún en el Nuevo Mundo. Pero su ensayo, y su tentativa, albergan contradicciones insalvables, al menos en los términos en que el problema queda planteado, y que la escritura misma de su ensayo pone en evidencia; porque disertar sobre "Io real maravilloso americano" excluye, si llevamos a sus últimas consecuencias el sistema spengleriano que maneja Carpentier, toda posible espontaneidad producto de una fe, de una falta de autoconciencia. Si lo real maravilloso sólo se descubre ante el creyente, ¿qué esperanzas puede tener de aprehenderlo y manifestarlo Carpentier? El problema de la reflexividad queda abierto, y también el del dualismo: las maravillas quedan del lado de allá, del lado de los afroantillanos, de los indios, a quienes Carpentier supone creyentes, y que pueblan sus ficciones. Pero ¿dónde queda Carpentier? No digamos ya el Carpentier que viaja por Haití con una compañía de actores franceses, sino el Carpentier implícito en sus relatos. Justo es decir que al llegar a este punto, la tentativa de Carpentier tropieza contra la problemática de la literatura hispanoameri-

gal, op. cit., el de Alegría es el único que merece lectura atenta entre los dedicados al tema. 
cana desde sus orígenes (desde Garcilaso el Inca) ¿pierde su autenticidad el hispanoamericano al poner pluma sobre papel y dejar correr la tinta? ¿Se va con ésta su esencia?

El realismo mágico, como concepto crítico, depende de coordenadas de pensamiento mucho más complejas y amplias que la literatura, aunque en su despreocupada aplicación se ha soslayado por otra parte la complejidad de la literatura misma, su especificidad. Georg Lukács, después de numerosas páginas de su Estética dedicadas al estudio de los orígenes del fenómeno literario desde una perspectiva antropológico-marxista, llega a la siguiente distinción: "es esencial a lo estético el concebir la reproducción refleja de la realidad precisamente como reflejo, mientras que la magia y la religión atribuyen realidad objetiva al sistema de sus reflejos y exigen la fe correspondiente. Para la evolución posterior eso tiene como consecuencia la contraposición decisiva consistente en que el reflejo estético se constituye como sistema cerrado en sí mismo (obra de arte), mientras que todo reflejo de naturaleza mágica o religiosa se refiere a una realidad trascendente." 51 En el plano teórico, el error de Carpentier, de los mundonovistas y de sus discípulos académicos, ha sido el confundir planos: el atribuir simultáneamente a la literatura realidad objetiva y vínculo con una (supuesta) realidad trascendente - la naturaleza americana, la conciencia hispanoamericana, etc. $Y$ a se ha visto que tanto la vertiente fenomenológica que parte de Roh, como la ontológica spengleriana y surrealista (estas dos facetas unidas por un mismo trasfondo romántico-naturalista), ofrecen un claro aspecto trascendental - velado en la primera por el término magia, subrayado en la segunda. Pero el deseo de abolir la diferencia entre el yo y el otro, entre el observador y el cosmos es socavado en ambos casos precisamente por el empleo de términos como magia y maravilloso. Toda magia, toda maravilla, supone una alteración del orden, una alteridad -supone al otro, al mundo, que nos mira desde la orilla opuesta. Octavio Paz describe así esta ambivalencia de la magia:

por una parte, [la magia] trata de poner al hombre en relación viva con el cosmos, $y$ en este sentido es una suerte de comunión universal; por la otra, su ejercicio no implica sino la búsqueda del poder. El ¿para qué? es una pregunta que la magia no se hace y que no puede contestar sin transformarse en otra cosa: religión, filosofía, filantropía. En suma, la magia es una concepción del mun-

51 Estética, v. 2, op. ciț., p. 40. 
do pero no es una idea del hombre. De ahí que el mago sea una figura desagarrada entre su comunicación con las fuerzas cósmicas y su imposibilidad de llegar al hombre, excepto como una de esas fuerzas. La magia afirma la fraternidad de la vida -una misma corriente recorre el universo- y niega la fraternidad de los hombres. ${ }^{52}$

¿No setá análogo el desgarro del escritor? Pero no es sólo esa característica distanciadora de la magia la que mina el impulso de Carpentier, sino además, su declaración de que lo maravilloso se encuentra en América, por oposición a Europa. Suponer que lo maravilloso existe en Américo es adoptar una (falsa) perspectiva europea, porque sólo desde otra perspectiva podemos descubrir la alteridad, la diferencia - lo mismo visto desde dentro es homogéneo, liso, sin aristas, sin diferencias. Toda maravilla es una distanciación, una separación. Todos los esfuerzos de la mejor intencionada crítica académica por dar nombre a un movimiento bajo el rótulo de realismo mágico, caen en esta contradicción, sin saberlo. La tradición ocultista que nos llega desde el romanticismo, pasando por la vanguardia y el surrealismo, tiene peculiaridades hispanoamericanas, pero no características radicalmente diferentes. Tal vez una de esas características sea precisamente la de que escritores como Carpentier, Asturias o Uslar Pietri, hayan declarado que la magia estaba aquí, para evadir la alienación del europeo para quien la magia siempre está allá. Pero en esa tentativa hay una doble o meta-alienación; la magia puede que esté en esta orilla, pero tenemos que verla desde la otra para verla como tal. La peculiaridad hispanoamericana será entonces ese doblez, esa atopía suspendida entre un aquí y un allá - viaje perpetuo, ruta en busca de una Antilla siempre elusiva. El error será el errar. La pregunta será entonces no si el hispanoamericano pierde su autenticidad al poner pluma sobre papel, sino cuestionar la base misma de esa pregunta. ${ }^{53}$

Insisto en que el "error" de Carpentier es sólo en el plano teórico de su ensayo, donde sus postulados aspiran a un estatuto de veracidad comprobable, no en el plano literario. Exigir a la literatura la comprobación de esos postulados setía caer en la misma equivocación de querer adjudicar a ésta una realidad objetiva, un nexo concreto con su referente. Por otra parte, si podemos pedir coherencia a los razonamientos de Carpentier en su ensayo, no podemos hacer lo mismo con sus relatos - nos

52 El arco y la lira, op. cit., p. 55.

53 Para una detallada historia analítica de este prejuicio, véase, sobre todo, "La violence de la lettre: de Lévi-Strauss à Rousseau", en Jacques Derrida, De la grammatologie (Paris: Editions de Minuit, 1967), pp. 149-202. 
es lícito asumir que no puede existir ese nexo concreto, mágico, entre la escritura y el cosmos, pero no podemos negar a la literatura el deseo de establecer ese nexo, porque en ese plano lo que en el ensayístico son pérdidas, en éste pueden ser ganancias. Esto es lo que parece sugerir Borges en su obra; que el texto literario se desplaza en el espacio entre un sí $y$ un no -entre un orden que se vislumbra y una dispersión que se anuncia.

Además, visto en el contexto de los relatos a los que alude, y cuya escritura intenta justificar, el ensayo-prólogo de Carpentier puede petder ese status teórico y definitorio que posee por aislado, e insertarse de manera más estratégica en el conjunto de la obra del narrador cubano.

$$
\text { III * }
$$

Esos circulos de nieve,
Esos doseles de vidrio
que el sol ilumina a rayos,
que parte la luna a giros,
esos orbes de diamantes
esos globos cristalinos,
que las estrellas adornan
y que campean los signos,
son el estudio mayor
de mis años, son los libros
donde en papel de diamante
en cuadernos de zafiros,
escribe con lineas de oro,
en caracteres distintos,
el Cielo nuestros sucesos,
ya adversos o ya benignos.

Basilio, La vida es sueño

Los relatos carpenterianos de los años cuarenta se distinguen, como ya se ha dicho, por su historicidad, por desarrollarse su acción en una época pasada, que se señala por trajes, costumbres, objetos, o a veces por incidentes pretéritos conocidos, cuando no por alusión directa a personajes históricos reconocibles: "Oficio de tinieblas", "Los fugitivos" y "Viaje a la semilla" se ubican en la Cuba de la aristocracia azucarera del siglo xrx (Santiago de Cuba y los alrededores de La Habana); El reino de este 
mundo en Santo Domingo y Santiago de Cuba a finales del siglo xvir y principios del xIx; "Semejante a la noche", que es, como he mostrado en otra acasión una especie de mise en problème de la narrativa y la historia, en seis momentos distintos que abarcan desde la Grecia homérica hasta el presente siglo, y "El camino de Santiago", en Flandes, Francia, España y Cuba durante el siglo Xvi."54 En el trabajo aludido sobre "Semejante a la noche" intenté mostrar cómo la historia se ficcionaliza (a pesal y a causa de su precisión), se literaturiza, por un lado mediante la repetición de lo mismo, y por otro mediante la asimilación de textos históricos de diversas épocas que se "citan" unos a otros, se funden en un mismo plano horizontal, anulando así su valor referencial. Ahora bien, si extendemos el problema de la escritura histórica a la problemática de la Historia (como acontecimientos reales), vemos que "Semejante a la noche" no representa más que la ideología spengleriana llevada a su conclusión más radical. Georg Lukács ya ha apuntado, en un reciente y autocrítico prólogo a su Teoría de novela, que Spengler, "by radically historicising all categories and refusing to recognise the existence of any suprahistorical validity, whether aesthetic, ethical or logical [...] abolished the unity of the historical process: his extreme historical dynamism finally became transformed into a static view, an ultimate abolition of history itself, a succession of completely disconnected cultural cycles which always end and always start again."'55 Lo que une todos esos ciclos dispersos y aparentemente disconexos, sin embargo, es la naturaleza, que es la única permanencia que queda del torbellino histórico spengleriano. Es ese estatismo histórico, no obstante, lo que caracteriza la narrativa carpenteriana de los años cuarenta. No se trata simplemente de que Carpentier ofrezca una visión descentrada, anti-hegeliana de la Historia, sino que el proceso histórico aparece como un ciclo dinámico de repeticiones que desemboca en lo estático y permanente, como los idénticos rayos de una rueda en movimiento proyectan una imagen fija. Por ello, el mundo histórico que presenta Carpentier en sus relatos es siempre un mundo de imponentes edificios y de ruinas - un mundo de palacios y mansiones desmanteladas. Pero, ¿dónde se ubica esa permanencia, esa acrónica y ucrónica isla siempre vista entre dos aguas que corren en direcciones opuestas? Si el resultado de la historicidad que ofrece Carpentier es la ahistoricidad, ¿en qué queda el proyecto de rescatar los orígenes y la historia americana? Y si

54 "'Semejante a la noche', de Alejo Carpentier: historia/ficción", Modern Language Notes, 87 (1972), 272-85. Ahora recogido en Asedios, op. cit.

55 The Theory of the Novel (Cambridge, Mass.: MIT Press, 1971), p. 16 El prólogo está firmado en Budapest, julio de 1962. 
esta última es esa permanente isla en medio de las corrientes de la historia, ¿cómo cifra su imagen en los textos históricos que Carpentier rescata $\mathrm{y}$ en los de su propia narrativa?

Para comprender más íntimamente y poder observar más de cerca toda esta problemática, conviene regresar al prólogo de El reino de este mando, a la parte en que Carpentier se refiere directamente a la composición de ese relato:

Sin habérmelo propuesto de modo sistemático, el texto que sigue ha respondido a este orden de preocupaciones [las vistas más arriba sobre "lo real maravilloso americano]. En él se narra una sucesión de hechos extraordinarios, ocurridos en la isla de Santo Domingo, en determinada época que no alcanza el lapso de una vida humana, dejando que lo maravilloso fluya libremente de una realidad estrictamente seguida en todos sus detalles. Porque es menester advertir que el relato que va a leerse ha sido establecido sobre una documentación extremadamente rigurosa que no solamente respeta la verdad bistórica de los acontecimientos, los nombres de personajes -incluso secundarios-., de lugares y basta de calles, sino que oculta, bajo su aparente intemporalidad, un minucioso cotejo de fechas y cronologias (p. 16, el subrayado es mío).

Quien haya leído a Carpentier con algún detenimiento no vacilará en tomar en serio sus palabras. Porque, en efecto, un conocimiento sumaric de los hechos narrados en El reino de este mundo parece confirmarlas. El relato narra acontecimientos conocidos: la revuelta de Mackandal, la rebelión de Bouckman, la llegada de colonos franceses a Santiago de Cuba a raíz de las convulsiones politicas de la isla vecina, las campañas del General Leclerc, el reinado de Henri Christophe, etc. Aun una investigación preliminar más minuciosa revelará que $M$. Lenormand de Mezy fue un colono rico de la región norteña de Limbé, en cuya hacienda, en efecto, ocurrió la primera revuelta de esclavos narrada en $E l$ reino de este mundo, la de Mackandal; que Rochambeau fue quien sucedió a Leclerc en la isla, que Labat y Moreau de Saint Méry (pp. 90-91) fueron en efecto historiadores de los sucesos, que Cornejo Brelle fue Corneille Breille, que Esteban Salas fue un compositor santiaguero que Carpentier descubrió en sus investigaciones para La música en Cuba, que hubo un esclavo llamado Noel. . . se Pero Carpentier reclama mucho más. Carpentier habla de no

56 La corroboración de muchos de estos datos puede encontrarse en, Moreau de Saint-Méry, Description topographique, pbysique, civile, politique et bistovi. 
haberse propuesto de modo sistemático alcanzar lo real maravilloso, que éste fluye "libremente de una realidad seguida en todos sus detalles", y de un minucioso cotejo de fechas y cronologías." Lo que reclama Carpentier, en otras palabras, es perfectamente consecuente con el resto de su teoría; que lo maravilloso surge espontáneamente de la realidad histórica americana y se cifra en su texto. Veámoslo más despacio.

Si tomamos algunos de los acontecimientos más memorables del relato, pronto nos damos cuenta de que el procedimiento utilizado por Carpentier en la composición de $E l$ reino de este mundo —que no varía en lo más mínimo del utilizado en "semejante a la noche" y otras narracioneses el collage, la superposición de textos históricos. Observemos dos escenas a las que habrá que regresar por otros motivos. En el capitulo en que Mackandal es ejecutado en la plaza pública del Cabo ( 8 de la primera parte), se lee:

El fuego comenzó a subit hacia el manco, sollamándole las piernas. En ese momento, Mackandal agitó su muñón que no había podido atar, en un gesto conminatorio que no por menguado era menos terrible, aullando conjuros desconocidos y echando violentamente el torso hacia adelante. Sus ataduras cayeron, y el cuerpo del negro se espigó en el aire, volando por sobre las cabezas, antes de hun-

que de la partie française de l'Isle de Saint-Domingue, originalmente publicada en Filadelfia en 1797, hoy asequible en la edición de Blanche Maurel y Etienne Taillemite (París: Société de L'Histoire des Colonies Françaises et Librairie Larose, 1958), 3 vols. Otros pueden ser corroborados en, Pierte de Vaisière, Saint-Domingue (1629-1789). La Société et la vié créoles sous lancien régime (París: Perrin, 1909), que es particularmente útil por su resumen sobre la vida de los colonos y de los negros (aunque mucho está tomado de Moreau de SaintMéry) y V. Schoelche, Vie de Tousaint-Louverture (Paris: Ollendorff, 1889), que aunque narra muchos episodios que el relato de Carpentier se salta, contiene varios capítulos detallados sobre el período hasta 1791. Util porque indica y copia documentos que Carpentier pudo haber tenido a su disposición en La Habana es el volumen: Documentos para la bistoria de Haití en el Arcbivo Nacional, compilados y ordenados por José Luciano Franco ( $\mathrm{La}$ Habana: Publicaciones del Archivo Nacional de Cuba, No 37, 1954); de gran utilidad es también el recuento histórico del compilador. Para el período republicano he consultado, entre otros, los siguientes volúmenes: Dantès Bellegarde, La nation bätienne (París: J. de Gigord, 1938); T. G. Stewart, The Haitian Revolution, 1791 to 1804 (Nueva York: Russel and Russel, 1914), y el compendio moderno más útil que conozca, James G. Leyburn, The Haitian People, intr. Sidney W. Mintz (New Haven: Yale University Press, 1966). He leído, por supuesto, el popular libro de C.I.R. James, The Black Jacobins (Nueva York: Vintage, 1963), que sirve de introducción, pero que a veces no cuenta con información precisa. Creo haber leído o consultado la mayoría de los libros consignados por Carpentier en la bibliografía de La música en Cuba (gracias a la inestimable colección sobre problemas relativos a la esclavitud de ia biblioteca Olin de Cornell), pero no me ha sido posible aún ver La Gazette de Saint-Domingue. 
dirse en las ondas negras de la masa de esclavos. Un solo grito llenó la plaza.

-Mackandal sauvé!

Y fue la confusión y el estruendo. Los guardias se lanzaron, a culatazos, sobre la negrada aullante, que ya no parecía caber entre las casas y trepaba hacia los balcones. $\mathrm{Y}$ a tanto llegó el estrépito y la grita y la turbamulta, que muy pocos vieron que Mackandal, agarrado por diez soldados, era metido de cabeza en el fuego, y que una llama crecida por el pelo encendido aullaba su último grito. Cuando las dotaciones se aplacaron, la hoguera ardía normalmente, como cualquiera hoguera de buena leña, y la brisa venida del mar levantaba un buen humo hacia los balcones donde más de una señora desmayada volvía en sí. Ya no habia nada que ver.

Aquella noche los esclavos regresaron a sus haciendas riendo por todo el camino. Mackandal había cumplido su promesa, permaneciendo en el reino de este mundo (65-66).

Si pasamos ahora a la Description topographique, physique, civile, politique et historique de la partie française de lisle de Saint-Domingue, publicada en 1797 en Filadelfia por Moreau de Saint-Méry, testigo de la época y a quien, como ya se dijo, Carpentier menciona en el relato ("aquel rubicundo y voluptuoso abogado del Cabo que era Moreau de Saint-Méry" pp. 90-91), leemos el siguiente párrafo:

Le hasard ayant voulu que le poteau où l'on avait mis la chaîne qui le saisissait fut pourri, les efforts violents que lui faisaient faire les tourments $\mathrm{du}$ feu, arrachèrent le piton et il culbuta par-dessus le bucher. Les nègres crièrent: Macandal sauvé; la terreur fut extrême; toutes les portes furent fermées. Le detachement de Suisses qui gardait la place de l'execution la fit évacuer; le geolier Massé voulait le tuer d'un coup d'épée, lorsque d'après l'ondte du Procureur-général, il fut lié sur une planche et lancé dans le feu. Quoique le corps de Macandal ait été incinéré, bien des nègres ćroyent, même à présent, qu'il n'a pas péri dans le supplice..$^{57}$

Tan ingenuo sería pensar que Carpentier simplemente copia la escena, como dejar de notar las evidentes adiciones y supresiones; el detalle que explica por qué Mackandal logra zafarse, el de que haya sido incinerado después de muerto, las damas que se desmayan en los balcones. El texto

57 Moreau de Saint-Méry, op. cit., v. 2, pp. 630-31. 
del relato suple o suprime detalles discretamente sobre un texto que se "respeta" en su integridad. El mismo proceso se puede observar en otra escena notable del relato, la de "El Pacto Mayor" (capitulo 2 de la segunda parte), cuando Bouckman convoca a los esclavos a un claro del Bois-Caiman para planear la revuelta. Es una noche de tormenta:

De pronto una voz potente se alzó en medio del congreso de sombras. Una voz, cuyo poder de pasar sin transición del registro grave al agudo daba un raro énfasis a las palabras. Había mucho de invocación y ensalmo en aquel discurso lleno de inflexiones coléricas $y$ de gritos. Era Bouckman el jamaiquino quien hablaba de esta manera. Aunque el trueno apagara frases enteras, Ti Noel creyó comprender que algo había ocurrido en Francia, y que unos señores muy influyentes habían declarado que debía darse la libertad a los negros, pero que los más ricos propietatios del Cabo, que eran todos unos hideputas monárquicos, se negaban a obedecer. Llegado a este punto, Bouckman dejó caer la lluvia sobre los árboles durante algunos segundos, como para esperar un rayo que se abrió sobre el mar. Entonces, cuando hubo pasado el retumbo, declaró que un Pacto se había sellado entre los iniciados de acá y los grandes Loas del Africa, para que la guerra se iniciara bajo los signos propicios. $\mathrm{Y}$ de las aclamaciones que ahora lo rodeaban brotó la admonición final:

-El Dios de los blancos ordena el crimen. Nuestros dioses nos piden venganza. Ellos conducirán nuestros brazos y nos darán la asistencia. Rompan la imagen del Dios de los blancos, que tiene sed de nuestras lágrimas; escuchemos en nosotros mismos la llamada de la libertad! (pp. 78-79)

Acudiendo ahora a la Vie de Toussaint-Louverture de V. Schoelcher, publicada en París, en 1889, leemos:

C'était une nuit de violent orage, les éclaires sillonaient le ciel et les échos des mornes retentissaient des éclats de la foudre. Boukman, fidèle aux superstitions africaines, fait des invocations magiques, et, comme inspiré du Grand Esprit, il prononce cet oracle au milieu de la tempête:

Bon Dié qui fait soleil, qui clairé nous en haut, qui soulevé la mei, qui fait grondé l'orage.

Bon Dié là, zot tendé, caché dans zon nuage, et là li gardé nous, li vouait tout ça blancs fait. 
Bon Dié la qui si bon ordonnin nous vengeance; li va conduit bras nous, li ba nous assistance.

Jetté potrait Dié blancs qui soif dlo dans zie nous; couté la libeté, qui parlé coeur nous tous. ${ }^{58}$

Los ejemplos podrían multiplicarse. Prácticamente todas las escenas capitales del relato están tomadas de textos históricos: la escena de la misa de la Asunción en que Cornejo Brelle se le aparece al atormentado Christophe, la escena del entierto del rey negro en el cemento húmedo, etc. Pero, evidentemente, no es esto lo que Carpentier quiere decir cuando habla del fluir libre de lo real maravilloso. La historia que nos relata es constatable, documentable, podríamos hasta aceptar que ésta simplemente se copia, se repite en su texto. Pero, ¿quién establece el vínculo? ¿Quién selecciona? No se trata simplemente aquí, sin embargo, del elemental problema estético de la selección, ya que Carpentier nos habla de un fluir libre, sino de la relación, de la concatenación de incidentes en el relato.

Es éste, evidentemente, un problema que ha preocupado a la crítica, que se ha preguntado si El reino de este mundo no es más que una serie de acontecimientos extraordinarios coleccionados un poco al azar, sin hilo argumental que los una. ${ }^{59}$ Una primera lectura del relato puede producir esa impresión: el relato no tiene argumento; no hay relación visible entre sus partes. ¿Qué tiene que ver la primera con la tercera, donde ni siquiera aparece M. Lenormad de Mezy? Ti Noel une con su presencia los diversos sucesos históricos, pero su pasividad no sirve más que para eso, para dar un testimonio de los hechos. Carpentier habla en su prólogo, sin embargo, de una "sucesión de hechos extraordinarios" (op. cit.) - ¿pero qué principio, qué razón, da lugar a esa sucesión? Si Carpentier afirma que la composición del relato surge de un fluir libre, la disposi-

58 Schoelcher, op. cit., pp. 30-31. Schoelcher of rece la siguiente traducción al francés corriente: "Le bon Dieu, quit fait le soleil qui nous éclaite d'en haut, qui soulève la mer, qui fait gronder l'orage, entendez-vous, vous autres, le bon Dieu est caché dans un nange, là il nous regarde et voit tout ce que font les blancs. Le bon Dieu des blancs commande le crime, par nous il veut les bienfaits! Mais Dieu qui est si bon nous ordonne la vengeance. Il va conduire nos bras, nous donner assistance. Brisez l'image du Dieu des blancs qui a soif de l'eau dans nos yeux, écoutez la liberté qui parle au coeur de nous tous" (p. 31).

59 Véase, Emil Volek, "Análisis e interpretación de El reino de este mundo", Homenaje a Alejo Carpentier (Nueva York: Las Americas Publishing Co., 1970), pp. 145-78. Este ensayo de Volek, lleno de sugestivas intuiciones, aunque lamentablemente algo desorganizado, formula una estructuta contrapuntística, con mucha razón; pero Volek no da con aquello que rige el contrapunteo, aduciendo una "estructura semántica" (Wolfgang Kayser) que no me parece satisfactoria. 
ción de la historia, su concordancia (si ésta existe) no puede partir entonces de un proceso borgiano de selección - la fuente, si creemos a Carpentier, tiene que ser otra.

$\mathrm{Si}$ la historicidad es una de las características más salientes de la narrativa carpenteriana de los años cuarenta, la complicidad entre la historia y la naturaleza es otra. En "Oficio de tinieblas" hay terremotos y epidemias que diezman la ciudad de Santiago de Cuba en fechas significativas, en "Los fugitivos" Perro y Cimarrón viven atentos a los ritmos naturales, en "El camino de Santiago" la constelación, las estrellas, guían al peregrino, en "Viaje a la semilla" la Marquesa muere ahogada en el río Almendares, a pesar de que una negra santera le ha dicho que se cuide de "lo verde que corre" (p. 86), en "Semejante a la noche" se sugierc que la historia es una alternancia entre el día y la noche, reiteración de las tinieblas. En El reino de este mundo esa complicidad entre la historia y la naturaleza atraviesa todo el relato: ya se ha visto que una gran tormenta acompaña la noche del "Pacto Mayor", Mackandal se vale de venenos confeccionados de yerbas y hongos para matar animales y colonos y dar comienzo a la primera rebelión de esclavos. En este nivel podríamos hablar de una especie de concordancia sinfónica (al estilo romántico y renacentista) entre los grandes sucesos y la naturaleza que se hace eco de ellos. Pero hay otro nivel en que esa complicidad se manifiesta: las profecías de Ti Noel. A propósito de los relatos de folklore y religión africanos que le hace Mackandal, Ti Noel afirma en el capítulo 6 de la primera parte: "Un día daría la señal del gran levantamiento [Mackandal], y los señores de Allá, encabezados por Damballah, por el Amo de los Caminos y por Ogún de los Hierros, traerían el rayo y el trueno, para desencadenar el ciclón que completaría la obra de los hombres. En esa gran hora - decía Ti Noel- la sangre de los blancos correría hasta los arroyos, donde los Loas, ébrios de júbilo, la beberían de bruces, hasta llenarse los pulmones" (p. 56). Estas profecias se cumplen, primero cuando en el "Pacto Mayor", donde, como ya se ha visto, el rayo y el trueno acompañan el ritual de conjuro, y en "La llamada de los caracoles", cuando los esclavos masacran a los colonos y corre la sangre, y al final, cuando el gran "viento verde" arrasa por completo y termina la destrucción que, en efecto, habían comenzado los hombres. ${ }^{60} \mathrm{La}$ cohesión del relato no es causal, sino contrapuntística, como ha sugerido Volek;

60 No es fortuito el uso del ciclón por parte de Carpentier, como símbolo de una fuerza cósmica apocalíptica. Precisamente en 1947 Fernando Ortiz publicaba un minucioso libro sobre la mitología del huracán, en el que numerosas páginas son dedicadas a los afroantillanos: El buracán. Su mitología y sus simbolos (México: Fondo de Cultura Económica, 1947). 
no es lineal, sino reiterativa. La naturaleza, conminada por los poderes de Mackandal y Bouckman, rige la historia y la disposición del relato, dándole unidad y coherencia, de la misma manera que el "Viaje a la semilla", el movimiento ritual del bastón del mago Melchor pone en movimiento la visión regresiva de la vida del Marqués de Capellanías. La complicidad, a este nivel, entre la naturaleza, el cosmos, y la historia, es clara; pero este es un nivel temático, o si se quiere, exclusivamente textual; además, como se ha visto al cotejar el texto de El reino de este mundo con textos históricos, hubo realmente una tormenta la noche del "Pacto Mayor", y si investigamos en otros textos históricos, veremos que el uso de venenos por Mackandal no responde simplemente a una necesidad textual, sino que fue un hecho histórico: "Pendant sa desertion. [Mackandal] se rendit célèbre par des impoisonnemens qui répandirent la terreur parmi les nègres, et qui les lui soumit tous. Il tenait école, ouverte de cet art exécrable, il avait des agents dans tous les points de la Colonie, et de la mort volait au moindre signal qu’il faisait." 61 ¿Será puramente textual entonces esa concordancia que se ha apuntado, o será histórica?

Si la historia y el texto se funden en una misma relación, si aquélla posee ya la disposición y concordancia que encontramos en éste, no se trata entonces, como en Borges, de una magia que relaciona simplemente al nivel textual, sino de un vínculo concreto y real entre el cosmos y la escritura. De ser así, la relación entre la historia y el relato no será simplemente la de la glosa o el suplemento que se ha visto al cotejar pasajes del relato con textos históricos, sino que deberá existir un riguroso ritmo cronológico concordante entre ambos - -una sintaxis común.

Aunque el texto del relato no lo registra, la noche del "Pacto Mayor" (escena citada más arriba) fue la del 14 de agosto de 1791, y la de "La llamada de los caracoles", 8 días después, como sí consigna el relato, la del 22 de agosto del mismo año. La fecha es comprobable: "Un sacerdote de culto $V u d u$, Boukman, negro natural de Jamaica, que ejercía un gran ascendiente sobre todos los esclavos que se le acercaban, convocó misteriosamente a un gran número de ellos para la noche del 14 de agosto de 1791 en un claro del Bois-Caiman [...] La sublevación estalló ocho días después de la ceremonia. .."62 El propio Carpentier narra el incidente y da las fechas en La música en Cuba: "La noche del 14 de agosto de 1791, se produce, en Santo Domingo, un gravísimo acontecimiento. Suenan los tambores del vudú en Bois Caiman. Bajo una lluvia torrencial, doscientos delegados de dotaciones de la Llanura del Norte,

61 Moreau de Saint-Méry, op. cit., p. 630.

62 José Luciano Franco, Documentos, op. cit., pp. 22-23. 
llamados por el iluminado Bouckman, beben la sangre tibia de un cerdo negro, juramentándose para la rebelión. Ocho días después volaba sobre las montañas la voz ronca de los grandes caracoles" (p. 100). Precisando aún más se encuentra que la noche del 14 de agosto fue un domingo, y la del 22 un lunes. ${ }^{63}$

Nada sorpresivo tiene la precisión de esas fechas hasta que nos damos con que la única fecha mencionada en el relato es la del 15 de agosto (capitulo 5 de la tercera parte, "Crónica del 15 de agosto"); el Domingo de la Asunción en que Henri Christophe, atormentado por su conciencia, cae fulminado durante la misa ante la visión de Cornejo Brelle. La proximidad de las fechas es llamativa, más aún cuando nos damos cuenta de que el capítulo siguiente, 6 de la tercera parte, cuando el rey se suicida, es también domingo ("El domingo siguiente", p. 153) -22 de agosto, por supuesto. Puede comprobarse que, en efecto, Henri Christophe fue víctima de una especie de embolia un 15 de agosto de 1820: "One Sunday, a few weeks later [después de la ejecución de Brelle; la nota indica: 'August 15th is the date usually given'], the king suddenly presented himself at the little parish church at Limonade and sent word to the priest that he desired to hear mass. The astonished curate made ready, but as he entered the chancel he was horrified to see the king rise, clutching his prie-Dieu, mutter the name of Corneille Brelle and fall forward in a faint, opening a deep gash in his forehead as it struck the pavement." ${ }^{84} \mathrm{El}$ relato parece seguir revelando una rigurosa precisión histórica y cronológica, y no registra aquí más que una coincidencia:

\begin{tabular}{|c|c|c|c|}
\hline & Domingo & Domingo & Lunes \\
\hline 1791 & $\begin{array}{l}14 \text { de agosto } \\
\text { (Pacto Mayor) }\end{array}$ & & $\begin{array}{l}22 \text { de agosto } \\
\text { (Llamada de los }\end{array}$ \\
\hline 1820 & $\begin{array}{l}15 \text { de agosto } \\
\text { (Misa de la } \\
\text { Asunción; apari- } \\
\text { ción de Brelle) }\end{array}$ & $\begin{array}{l}22 \text { de agosto } \\
\text { (Ultima ratio } \\
\text { regum) }\end{array}$ & caracoles) \\
\hline
\end{tabular}

La coincidencia, desde luego, estribará en que la ceremonia que anuncia la caída del régimen blanco en Haití ocurre un domingo 14 de agosto, y el levantamiento que echa a andar la rebelión ocurre un lunes 22 de

63 Siempre que doy días de la semana lo hago acudiendo al "Easy Reference Calendar" de Whitaker 1973 (Londres: Clower \& Sons, 1972), pp. 194-95.

64 Charles Moran, Black Triunvirate. A Study of Louverture, Dessalines, Christopbe - The Men IWho Made Haiti (Nueva York: Exposition Press, 1957), pp. 145-46. 
agosto; mientras que la ceremonia de la misa, donde ocurre el incidente que anuncia la caída del régimen negro ocurre un domingo 15 de agosto, y su muerte el 22 del mismo mes. La coincidencia es notable, y vincula acontecimientos en un ritmo de repeticiones cíclicas, pero no del todo histórica, ya que Henri Christophe no murió un domingo 22 de agosto, sino un domingo 8 de octubre de $1820 .{ }^{65}$ Además, por un lado tenemos un domingo y un lunes, mientras que por el otro dos domingos. La ruptura entre historia y relato se abre, pero hay más.

La sugerencia de un orden subyacente a estos esquemas cronológicos se hace más fuette si nos damos cuenta que "El Pacto Mayor", que es el capítulo 2 de la segunda parte, es el diez de la novela si contamos consecutivamente, y que por lo tanto, "La llamada de los caracoles" es el número once; mientras que, siempre contando consecutivamente, la "Crónica del 15 de agosto" es el número veinte y la "Ultima Ratio Regum" el veintiuno. Si con esta sospecha de disposición numérica regresamos a la primera parte del relato, notamos que la ejecución de Mackandal, quien como ya se ha visto da comienzo a la serie de sucesos históricos que componen $E l$ reino de este mundo, fue, según reza el texto, "Un lunes de enero", o sea, primer día del primer mes... Sólo que si acudimos a 1o historia veremos que Mackandal fue ejecutado un 20 de enero de 1758 , viernes. ${ }^{66}$ Conviene, de todos modos, notar que el capítulo en que se narra la ejecución de Mackandal, "El gran vuelo", es el 8 de la primera parte, y del relato, mientras que el anterior, cuando aparece Mackandal súbitamente durante una ceremonia vudú, tiene que caer, si la cronología no nos falla, un 25 de diciembre (Navidad, además) de 1757, domingo. ${ }^{67}$ Capítulo 8, un lunes de enero de 1858; la revuelta de Bouckman se planea para 8 días más tarde, un lunes -el 8 tendrá siempre que ser un lunes, comienzo del ciclo, de la semana, de los acontecimientos. El 7 será domingo; capítulo 7 de la primera parte, $25(2:+5=7)$ de diciembre de 1757 (diciembre será el mes 12, enero el 13; ceremonia, principio). En un brillante artículo sobre Los pasos perdidos, Eduardo G. González ha mostrado cómo funciona, con gran precisión, la Semana en esa novela, y cómo el domingo es "Final y Principio, apertura hacia el

${ }^{65}$ Hubert Cole, Christopbe, King of Haiti (Nueva York: Vikings Press, 1967), p. 286.

66 Moreau de Saint-Méry, op. cit, p. 630.

67 No es histórico que sea el 25 de diciembre, aunque sí el que se organizara una calenda para festejar el nacimiento de un hijo en la "habitación" de Dufresne (Dufrené en el relato), como se consigna en Moreau de Saint-Méry, op. cit. Tampoco dice el texto del relato directamente que sea un dia de Navidad, pero las sugerencias son demasiado fuertes como para no ser tomado como tal. 
ámbito creador." 88 En el reino de este mundo el domingo será el día de los grandes rituales anunciatorios, el lunes el día de los grandes acontecimientos. El domingo que faltaba al esquema anterior era el de la aparición de Mackandal un 25 de diciembre durante una ceremonia vudú; escena cuyo paralelismo con la de la aparición de Brelle no podía ser más claro; el otro lunes sería entonces (aunque no se narra) el de la toma del Cabo y de Sans Souci por los rebeldes (que serían luego dominados por Boyer, el presidente mulato de la zona sur). Resumiendo:

\section{Domingo}

Ti Noel visita la gruta de Mackandal, donde éste prepara los venenos, mueren los primeros animales ("Aquel mismo domingo", p. 46).

La primera mujer de $\mathrm{M}$. Lenormand de Mezy muere un domingo de Pentecostés (p. 49).

25 de diciembre de 1757, aparición de Mackandal en medio del festival vudú.

14 de agosto de 1791, "El Gran Pacto".

15 de agosto de 1820, Misa de la Asunción, aparición de Cornejo Brelle.

22 de agosto de 1820 , tambores y revueltas en el Cabo, conjurando la muerte de Christophe ("tronaban los tambores radás, los tambores congós, los tambores de Bouckman, los tambores de los Grandes Pactos". El subrayado es mío, p. 159).

\section{Lunies}

Ejecución de Mackandal un lunes de enero, "gran vuelo", los negros creen haber vencido.

22 de agosto de 1791, rebelión de Bouckman.

23 de agosto de 1820 (no narrado), caída del gobierno de Christophe.69

Doy, por supuesto, sólo los domingos y lunes que he podido comprobar a base de evidencia textual e histórica, pero tal vez puedan encontrarse otros con más amplias y minuciosas investigaciones. Lo significativo, sin embargo, es que Carpentier ha sometido la historia a una

68 "Los pasos perdidos, el Azar y la Aventura", Revista Iberoamericana, 81 (1972), p. 612. La importancia de las fechas en la obra de Carpentier fue notada por vez primera en el trabajo de Frances Wyers Weber, "El acoso: Alejo Car" pentier's War on Time", PMLA, 68 (1963), 440-448, y luego en, Roberto González Echeverría, "Ironía y estilo en Los pasos perdidos, de Alejo Carpentier", recogido en Asedios, op. cit., pp. 134-46. Carpentier utiliza de manera aún más explícita la estructura de la semana en su reciente relato $E l$ derecho de asilo.

$69 \mathrm{La}$ incidencia de ese mes de agosto es tan grande en el relato que no puede dejar de notarse que es justamente ese mes el de mayor peligro de huracanes en la isla, por lo cual pudiera conjeturarse que es también en agosto que termina $E l$ reino de este mundo. Véase, Ivan Ray Tannehill, Hurricanes 2nda. ed. (Princeton: Princeton University Press, 1943), p. 63. 
alternancia ritual de domingos y lunes, y ha montado el texto del relato en una armazón numérica cuya sutileza y complejidad, me temo, sólo he comenzado a vislumbrar, porque de seguro hay más concordancias. Por ejemplo, la novela tiene 26 capítulos, por lo tanto, el centro de la misma es el capítulo 13, "Santiago de Cuba", donde llega M. Lenormand de Mezy con Ti Noel a fines de 1791. Además del significado que Santiago de Cuba tiene por otras razones que se verán en seguida, sospecho que no sólo es el centro matemático del relato, sino también el cronológico. $\mathrm{Si}$ atendemos a la cronología que se ha ido develando, puede conjeturarse tal vez lo siguiente: sabemos que Mackandal fue ejecutado en enero de 1758, por lo tanto, como ya se dijo, el capítulo anterior, el 7, transcurre durante diciembre de 1757. Pero como en el capítulo 6 se ha dicho que transcurren cuatro años desde las primeras aventuras del mandinga (p. 57), el relato debe comenzar entonces en 1753. De ser así, transcurren 37 años antes de 1791 (que sería el año 38 de la acción), por lo cual me parece lícito conjeturar que otros 37 años transcurren después de ese capitulo, con lo cual el relato terminaría en 1828, durante la presidencia de Boyer (termina, desde luego, durante su presidencia, pero me ha sido imposible determinar el año, aunque debe ser después de 1824, cuando las princesas llegan a Italia); $;^{70}$ la acción duraría entonces 75 años ("época que no alcanza el lapso de una vida humana", dice Carpentier en el prólogo, p. 16). La sugerencia redondez de esos números es demasiado fuerte para no hacer conjeturas: $3+7=10 ; 2+8=10 ; 7+5=12$.

Hay, además, otras concordancias numéricas que tienden a corroborar esas conjeturas, y que son, además, reveladoras en sí. Acaba de decirse que el capítulo 13 es el centro del relato, dado que éste tiene 26 , si contamos consecutivamente. Desde luego, podría argüirse con toda lógica que no puede ser así, ya que si el capítulo 13 es el centro matemático de la narración, quedan 12 capítulos de un lado y 13 del otro. Sin embargo, con un poco más de atención pronto emerge lo siguiente: el capí. tulo 12 (II, 4) y el 25 (IV, 3), cierran ciclos. En el 12, aparece M. Lenormand de Mezy oculto en un pozo seco después de la sublevación del 22 de agosto de 1791 que ha arrasado con su casa; en el 25 aparece

70 Cole, op. cit. Las princesas llegan a Pisa, no a Roma, como se dice en el relato. El final del relato tiene que ser después de 1826 , cuando Boyer pasa el Código Rural, cuyo efecto en El reino de este mundo es la llegada de los agrimensores, y demás detalles dados en el texto sobre la conducta de los mulatos. Es concebible que, dado que ahora se gobierna desde el sur, desde Port-au-Prince, de donde vienen los agrimensores, tarde hasta el 28 la aplicación del Código a la región norte. No he podido comprobarlo ni históricamente ni en el texto del relato aún. Para detalles precisos sobre esta época de la historia de (lo que ya por esta fecha se llama Haití), ver Leyburn, op. cit., p. 66 y siguientes. 
Ti Noel refugiado, primero en la chimenea, y luego bajo una mesa en los escombros de la misma casa, después de la llegada de los agrimensores, que van a desmembrar y répartir la hacienda; el capítulo 13 (II, 5) será el último en que aparece vivo M. Lenormand de Mezy; el 26 (IV, 4), marcará la muerte de Ti Noel, y el final del relato. En el capitulo 13 (II, 5), M. Lenormand de Mezy aparece, después de la destrucción, en una urca, especie de Arca de Noé, que lo lleva a él y a otros colonos arruinados a Santiago de Cuba; en Santiago, ciudad famosa por sus carnavales, encontramos precisamente, en ese mismo capítulo, el carnaval, el teatro, la entrega a los rituales de la carne. En el capítulo 26 (IV, 4), tenemos la apocalipsis final, el "viento verde" que arrasa con todo. ¿No serái significativo que el capítulo 13 sea el quinto de la segunda parte $(5+2=7)$, y el $26(2+6=8)$ sea el cuarto de la cuarta parte $(4+4=8)$ ? Ese 7 y ese 8 , ese Domingo y ese Lunes-Carnaval y Apocalipsis - son los polos entre los cuales queda suspendida la acción; acción que se presenta en dos ciclos perfectos de 12 capitulos.

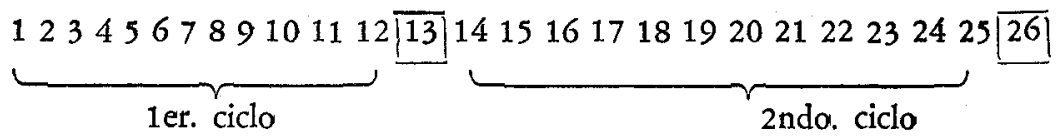

Y, en vista de lo anterior, ¿podtá ser fortuito el que, contando consecutivamente, el domingo de la aparición de Mackandal sea el séptimo capítulo del primer ciclo, y la aparición de Brelle el domingo de la Asunción sea el séptimo del segundo, y que la muerte de Mackandal y la de Christophe ocurran también en capítulos paralelos?

1

\section{2}

3

4

5

6

$7 \mathrm{I}, 7$

8 I, 8

9

10

11

12

13 Carnaval
1

2

3

4

5

6

7 III, 5

8 III, 6

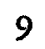

10

11

12

13 Apocalipsis 
El significado del sistema numético-simbólico en que la acción de $E l$ reino de este mundo aparece montada no podía ser más claro ahora. Por un lado es evidente que Carpentier presenta la historia como una serie de repeticiones cíclicas. Ti Noel, en el capitulo semifinal del relato se percata de ello cuando, ya demente y senil, quiere escapar a un mundo de hormigas: "Transformado en hormiga por mala idea suya, fue obligado a llevar cargas enormes, en interminables caminos, bajo la vigilancia de unos cabezotas que demasiado le recordaban los mulatos de ahora" ( $p$. 191). Hay, además, toda una serie de "ecos y afinidades", para emplear una terminología borgiana, a lo largo de la narración, algunas de las cuales ya se han visto. ${ }^{71}$ Existen, además, resonancias bíblicas y litúrgicas que van más allá del sistema numérico de la semana y del doce: ${ }^{72}$ el nombre de Ti Noel, que sugiere que nació un día de Navidad, más el hecho de que tenga doce hijos, hace de él una especie de figura Christi; la Navidad en que aparece Mackandal, el Domingo de Pentecostés en que muere la primera esposa de $M$. Lenormand de Mezy, el Domingo de la Asunción en que aparece Brelle, la alusión al Domingo de Ramos casi al final (p. 183). Y, sobre todo, el vaivén cósmico entre Carnaval y Apocalipsis. Todas estas repeticiones rituales, todo ese esfuerzo por aparejar la acción del relato al año litúrgico, son un intento de fundir el cosmos con la escritura. No hay que olvidar que Carpentier pretende insertar en todo este mecanismo la historia real, representada por esa rigurosa cronología y documentación de que habla en el prólogo, y cuyo perfil se ha visto más arriba. La concordancia numérica entre la historia y el cosmos representa - como en la literatura medieval, como en Dante - la fusión entre ésta y la naturaleza, entre la historia y la obra de una divinidad todopoderosa que ha creado el universo bajo medida, número y peso perfectos:

Creatori serviunt omnia subjecta, Sub mensura, numero, pondere perfecta.

71 Volek ha notado otras: "Los negros, que han derribado a unos amos, han sido esclavizados por otros, aunque de sus propias filas. Sin embargo, la historia se repite también en otro aspecto - el rey negro Henri Christophe suscita la ira del pueblo, queda aislado y abandonado y es barrido por él. En grotesca soledad medita sobre las causas de su caída. Genéricamente [?] se repite la situación: él también ha tratado de ignorar el 'vaudou', es decir, el espiritu del pueblo negro, apoyándose en la ideología católica, tal vez para verse superior a los 'ritos bárbaros; pero ésta le traiciona en el momento decisivo". Op. cit., p. 157.

72 El aspecto religioso del relato ha sido analizado de forma superficial e incompetente por Graciela Maturo en "Religiosidad y Liberación en Ecué-Yamba-O! y El reino de este mundo", Historia y mito en la obra de Alejo Carpentier, ed. Nora Mazziotti (Buenos Aires: Fernando Garcila Cambeiro, 1972), pp. 53-86. 
Ad invisibilia, per haec intelecta,

Sursum trahit homine ratio directa. ${ }^{73}$

La magia, la maravilla, será la concordancia entre la disposición numérica de la historia y la del texto: mediante ella se salvará la dualidad entre el ser y el cosmos a que Octavio Paz se refería al hablar del surrealismo, por ella también se manifestatía el milagro creíble, documentable, de esa fe a la que aspira Carpentier. Podría entonces hablar a través de él lo maravilloso, inscripto en el texto sin habérselo propuesto sistemáticamente; especie de escritura automática en que un cosmos pitagórico y platónico dejase grabados sus armónicos guarismos, las estelas leves de sus giros. El Libro, del que el texto de Carpentier no sería más que una copia o un fragmento, incluiría en su inmensa y compleja concordancia, el diseño total del universo. Pero la mano de Carpentier ha aparecido ya varias veces en el acto de añadir, en el acto de romper y violar ese supuesto orden naturaleza-historia para forzarlo a ceñirse a la ruta de su escritura: en la muerte de Henrí Christophe, que no ocurrió un domingo 22 de agosto, en la de Mackandal, que no fue un lunes sino un viernes de enero... Además, ¿hasta dónde es coherente esa numerologia? Si aceptamos que es consecuente que el capítulo 13 sea, en El reino de este mundo, el capítulo del Carnaval, dado que 13 sería enero, y ese es el mes según la liturgia que da comienzo al carnaval, ¿cómo es que Mackandal muere en

73 Citado por Robert Ernst Curtius, European Literature and the Latin Middle Ages (Nueva York: Harper and Row, 1953), p. 504. Sobre este tema, ver el capítulo de Curtius, "Numerical Composition", que además ofrece una iniciación bibliográfica al mismo. En un trabajo dedicado al estudio del sistema numérico de la Divina Commedia, Charles S. Singleton se hace la inevitable pregunta de para quién había dispuesto el poeta tan intrincado y oculto sistema. Su respuesta merece repetirse: "One may perhaps suggest the answer to such a question by turning it another way, by directing it, say, to Chartres Cathedral, to some sculptured and finely finished detail in the stone work on the roof of that great edifice, a detail as carefully wrought as any on the façade itself, but which, being where it is, might never be seen again by human eye, once the roof was finished and the workmen had withdrawn - unless someone should climb up to repair that roof and happen to take notice of it. But may we think that any such consideration even occurred to the master who designed that detail or to the stonemason who fashioned it with loving care? We may not, for we know that such an edifice was not addressed to human sight alone, indeed not primarily to human sight at all. He who sees all things and so marvelously created the world in number weight and measure, would see that design, no matter where its place in the structure; and would surely see it as a sign that the human architect had indeed imitated that created Universe which the Divine architect had wrought for His own contemplation, first of all, and for that of angels and men". "The Poet's Number at the Center", Modern Language Notes, 80 (1965), p. 10. Sin abusar aquí de la conocida relación de Carpentier con la arquitectura, y desde luego, Ia música, cabe preguntarse si no habrá algo similar entre lo dicho por Singleton sobre Chartres y la Commedia, y la obra del escritor cubano. 
enero? "Para percibir la distancia que hay entre lo divino y lo humano - dice Borges en 'La biblioteca de Babel'-, basta comparar estos rudos símbolos trémulos que mi falible mano garabatea en la tapa de un libro, con las letras orgánicas del interior: puntuales, delicadas, negrísimas, inimitablemente simétricas."74 La disposición numérica, la concordancia en el texto carpenteriano, no conduce a una $f e$, sino a formular la existencia de uno de esos dioses menores de Borges, que montan un complejo y preciso juego de afinidades para perecer en el reino de este mundo al completar su tarea. $Y$, en efecto, quien rige el reino de este mundo es precisamente el ángel caído, Satanás, a quien alude Carpentier en el epígrafe de su relato, el mismo que aparece al final de "El camino de Santiago", el que preside, sin duda, en la disipada vida de M. Lenormand de Mezy, a quien rinde culto la sensual Paulina Bonaparte y el soberbio y ambicioso Christophe. ${ }^{75}$ Sólo que ese orden que el demonio logra urdir -recuérdese El mágico prodigioso de Calderón-, como el del escritor, no es más que un simulacro, una impostura, un engaño. La creación de un ornado orden con pretensiones de permanencia, a sabiendas, y con la (mala) conciencia de su inminente disolución -el apego a lo efímero tangible. Litúrgico y grave -calderoniano-, Carpentier erige discretos monumentos para quedar atrapado en ellos, como Henrí Christophe muerto en su laberinto. (La escritura barroca será siempre el epitafio cincelado en las ruinas, porque todos los carnavalescos treces no anuncian sino la aniquilación y el desengaño).

El prólogo-epilogo de $E l$ reino de este mundo es también parte del engaño, de la mascarada barroca; es la última/primera máscara de Carpentier en el relato, la afirmación de una presencia que se niega y afirma a la vez -es el Carnaval. El (falso) postulado de una ontología americana, de la presencia (apócrifa) de "lo real maravilloso."

Conviene preguntarse en este punto si la disposición que se ha visto en $E l$ reino de este mundo es característica únicamente de ese relato, y

74 Ficciones (Buenos Aires: Emecé, 1956), p. 87.

75 "Hubo una batalla en el cielo: Miguel y sus ángeles peleaban con el dragón, y peleó el dragón y sus ángeles, y no pudieron triunfar ni fue hallado su lugar en el cielo. Fue arrojado el dragón grande, là antigua serpiente, llamada Diablo y Satanás, que extravía a toda la redondez de la tierra, y fue precipitado en la tierra, y sus ángeles fueron con él precipitados. Oí una gran voz en el cielo que decía. Ahora llega la salvación, el poder, el reino de nuestro Dios y la autoridad de su Cristo, porque fue precipitado el acusador de nuestros hermanos, el que los acusaba delante de nuestro Dios de día y de noche. Pero ello le han vencido por la sangre del Cordero y por la palabra de su testimonio y menospreciaron su vida hasta morir. Por eso, regocijaos, cielos y todos los que moráis en ellos. 'Ay de la tierra y de la mar!, porque descendió el diablo a vosotras animado de gran furor, por cuanto sabe que le queda poco tiempo" Apocalipsis, 12; 7-12. 
analizar en mayor detalle esa escena-bisagra que articula las dos partes del relato.

Lo que caracteriza esa escena central, ese eje o centro sobre el cual gira el relato es, como ya se ha dicho, el Carnaval, el teatro, la entrega a las llamadas de la carne, pero además, la inversión de las jerarquías, la indeterminación. La escena es un momento barroco de frenesí y desenfreno sensual ante los avisos de muerte; afirmación de la vida en sus aspectos más tangibles ante la amenaza de aniquilación inminente:

Mientras otros, más previsores en lo de sacar dinero de Santo Domingo, pasaban a la Nueva Orleans o fomentaban nuevos cafetales en Cuba, los que nada habían podido salvar se regodeaban en su desorden, en su vivir al día, en su ausencia de obligaciones, tratando, por el momento, de hallar el placer en todo. El viudo redescubría las ventajas del celibato; la esposa respetable se daba al adulterio con entusiasmo de inventor; los militares se gozaban con la ausencia de dianas; las señoritas protestantes conocían el halago del escenario, luciéndose con arrebol y lunares en la cara. Todas las jerarquías burguesas de la colonia habían caído. Lo que más importaba ahora era tocar la trompeta, bordar un trío de minué con el oboe, y hasta golpear el triángulo al compás, para hacer sonar la orquesta del Tivoli. (pp. 94-95)

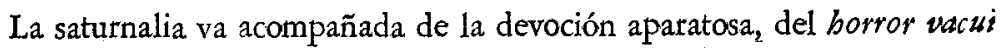
que lanza a los personajes hacia las formas más palpables del culto; a las devociones teatrales y a los templos ornados, a los signos y símbolos del barroco eclesiástico: "Masón en otros tiempos, desconfiaba [Lenormand de Mezy] ahora de los triángulos noveleros. Por ello, acompañado por Ti Noel, solía pasarse largas horas, gimiendo y sonándose jaculatorias, en la catedral de Santiago" (p. 97); "Los oros del bartoco, las cabelleras humanas de los Cristos, el misterio de los confesionarios recargados de molduras, el can de los dominicos, los dragones aplastados por santos piés, el cerdo de San Antón..." (p. 98). Si, como ya se ha visto, la historia aparece como un ciclo de repeticiones inexorables, la escena-eje, el centro de la narración es precisamente la celebración del paso de un ciclo a otro; celebración que anuncia el principio y marca el final, que suspende momentáneamente la disolución, que la enmascara y la anuncia; signo doble del barroco. Si fuese en El reino de este mundo únicamente que aparece esta estructura litúrgica, y ese centro carnavalesco y barroco, 
podria dudarse de las concordancias que hemos encontrado en la disposición del relato. Pero, por el contrario, los demás relatos de la época exhiben un arreglo similar.

"Oficio de tinieblas", como ha escrito Klaus Müller-Bergh en un fino artículo, y como su título sugiere, fue compuesto por Carpentier "en estrecho paralelo a las nueve oraciones que comprenden el primer oficio del Viernes Santo". ${ }^{76}$ No sólo eso, sino que los acontecimientos narrados en el cuento abarcan un año, que se ofrece a modo de año litúrgico que concuerda con hechos históricos (el célebre terremoto de Santiago de Cuba). ¿Será fortuito que los capítulos intermedios traten del Carnaval uno y del teatro el otro? En "Viaje a la semilla" la acción del relato, en que se narra retrospectivamente toda la vida de Marcial, el Marqués de Capellanías, ocurre en 12 horas, y se divide en 13 capítulos. ¿Será entonces fortuito que a finales del capítulo 6 se diga que "se estaba de Carnavales", y que sea justo en ese capítulo en que Carpentier presente una de sus escenas favoritas, la de los trajes, con sus claras resonancias calderonianas de $\mathrm{El}$ gran teatro del mundo?

En entrepaños escarchados de alcanfor descansaban los vestidos de corte, un espadín de Embajador, varias guerreras emplastronadas, el manto de un Príncipe de la Iglesia, y largas casacas, con botones de damasco y difuminos de humedad en los pliegues. Matizáronse las penumbras con cintas de amaranto, miriñaques amarillos, túnicas marchitas y flores de terciopelo. Un traje de chispero con redecillas de borlas, nacido en una mascarada de carnaval, levantó aplausos. La de Campoflorido redondeó los hombros empolvados bajo un rebozo de color de carne criolla, que sirviera a cierta abuela, en noche de grandes decisiones familiares, para avivar los amansados fuegos de un rico Síndico de Clarisas. (pp. 90-91)

¿Poidrá pasarse por alto que se celebra en ese capitulo la mayoría de odad de Marcial, y que sea en el capítulo 12 cuando complete su regressus ad uterum? ¿Y que sea en el capítulo 6 que Marcial en un sueño vea los muebles por el techo y los relojes marchando en sentido opuesto? En "Viaje a la semilla" la acción queda enmarcada por dos nadas, la prenatal y la muerte, con un centro que es el Carnaval -el emblema del relato

78 "'Oficio de tinieblas', un cuento escasamente conocido", Asedios, op. cit., pp. 53-62. 
es esa Ceres que es diosa de la plenitud de las cosechas y de la región subterránea de los muertos. ¿Y no es la Feria de Burgos el eje sobre el cual giran, como ha mostrado Sharon Magnarelli, los dos ciclos que componen "El camino de Santiago"? 77

"Los fugitivos", el relato más "primitivo" de Carpentier en los años cuarenta permite ver de manera aún más sinóptica y precisa la alternancia Carnaval-Apocalipsis que se ha venido observando en El reino de este mundo y otras narraciones de la época. El relato es una especie de parábola. El negro cimarrón (cuyo único nombre en el relato es Cimarrón) escapa de los barracones del central azucarero, pero cede a la tentación del alcohol y las mujeres y es capturado; luego, cuando trata de escapar de nuevo, el perro (Perro en el relato) que le había acompañado en su primera escapatoria, es quien lo destroza. Lo que condena a Cimarrón es la superfluidad de sus deseos y acciones. Cuando vive en la manigua con Petro, a ambos los asedia el deseo sexual cuando llega la primavera, pero Cimarrón continúa su disipación sexual después de cumplido el ciclo natural, mientras que Perro: "Pasada la crisis de primavera [...] se mostraba cada vez más reacio a acercarse a los pueblos". ${ }^{78}$ La causa de esa superfluidad se da en una escena casi alegórica. Perro, escarbando en la gruta en que vive con Cimarrón, desentierra unas reliquias: "Un día, Perro comenzó a escarbar al pie de una de las paredes. Pronto sus dientes sacaron un fémur y unas costillas, tan antiguas que ya no tenían sabor, rompiéndose sobre la lengua con desabrimiento de polvo amasado. Luego, llevó a Cimarrón, que se tallaba un cinto de piel de majá, un cráneo humano. A pesar de que quedasen en el hoyo unos restos de alfarería y unos rascadores de piedra que hubieran podido aprovecharse, Cimarrón, aterrorizado por la presencia de muertos en su casa, abandonó la caverna esa misma tarde, mascullando oraciones, sin pensar en la lluvia" (p. 30). El terror de la muerte se cierne sobre el negro ante los restos taínos; otros antes que él han vivido en la cueva, y han dejado sus ruinas - su destino será repetir el mismo destino, dejar sus huesos como signos de un pasado. Como un Hamlet con la calavera de Yorick, Cimarrón toma conciencia de su propia mortalidad, y ésta lo saca de los ritmos naturales y lo lanza al vicio y los excesos. No es fortuito entonces que ese mismo día -que bien puede ser el de la muerte de Marcial pues el cura lleva el

77 Ver las páginas 69-90 de este número de la Revista Iberoamericana.

78 Cito por Narrativa cubana de la Revolución, ed. J. M. Caballero Bonald (Madrid: Alianza, 1968), p. 33. En lo sucesivo se consigna en el texto el número de páginas. El cuento es de 1946; ver, "Notas para una cronología..." op. cit. 
viático al central - sea el mismo en que aparece la escena carnavalesca y teatral de los trajes. Perro espanta la calesa en que Gregorio lleva al cura y ambos mueren cuando ésta se vuelca. Cimarrón "se apoderó de la estola y de las ropas del cura, de la chaqueta y de las altas botas del calesero. En bolsillos y bolsillos había casi cinco duros. Además, la campanilla de plata. Los ladrones regresaron al monte. Aquella noche, arropado en la sotana, Cimarrón se dio a soñar con placeres olvidados" (p. 31). Vuelco, inversión, muerte, disfraces, sensualidad, los signos de la escena carnavalesca reducidos aquí al mínimo, pero todos presentes en su lugar asignado. La acción del relato abarca dos años y tres primaveras: en la primera aparece Perro persiguiendo a Cimarrón, en la tercera se repite la escena, pero esta vez Perro opta por matar al negro -es poco antes de la segunda primavera, la central, que ocurre la escena carnavalesca antes vista. La repetición de la primera escena anula la necesidad de la voluta del argumento: es como si estuviéramos siempre al principio y se nos diese otro posible desenlace. Lo que queda entre ambas repeticiones es, así, superfluo, carnavalesco, barroco, como son las acciones del negro allí narradas que lo llevan, a pesar de sus esfuerzos, a cumplir el destino que había intentado esquivar: "Durante muchos años - dice la última oración del relato- los monteros evitaron, de noche, aquel atajo dañado por huesos y cadenas" (p. 37). ¿Irán esos monteros, de noche, a visitar como Cimarrón las prostitutas del pueblo?

Los huesos y cadenas que Cimarrón deja son los signos de su tránsito por el reino de este mundo - son sus ruinas, su Sans Souci, y son emblemáticos del aditamento que el hombre impone a la naturaleza. Desde la perspectiva de Perro: "Los hombres suelen dejar sus buesos y desperdicios por donde pasan. Pero es mejor cuidarse de ellos, porque son los animales más peligrosos, por ese andar sobre las patas traseras que les permite alargar sus gestos con palos y objetos" (p. 36; el subrayado es mío). Atrapado en el mecanismo de los ritmos inexorables de la vida y la muerte que la naturaleza impone al hombre -entre domingos y lunes-, el hombre deja con sus ruinas la huella de su paso. En El reino de este mundo no son sólo las ruinas de esos excesos - palacios, fortalezas, mansiones, el Coliseo de Roma- lo que dejan los hombres, sino sus propios cuerpos como monumentos fríos: Christophe deja su cadáver fundido con la argamasa de su fortaleza: "La montaña del Gorro del Obispo, toda entera, se había transformado en el mausoleo del primer rey de Haiti" (p. 168); las tibias y trémulas carnes de Paulina Bonaparte se metamor- 
fosean en la fría estatua que Solimán soba en el Palacio Borghese; la imagen del Rey Mago Melchor se anuncia en las blancas córneas de Bouckman y de Solimán; y desde la primera escena, la aparición de las cabezas de cera anuncian el destino de M. Lenormand de Mezy. Las resonancias barrocas de esta petrificación somática son demasiado fuertes para no ser tomadas en cuenta:
Falleció César, fortunado y fuerte; ignoran la piedad y el escarmiento señas de su glorioso monumento; porque también para el sepulcro hay muerte.7\%

"Para el sepulcro hay muerte", dice Quevedo, pero éste, como el cuerpo, "sepultura portátil" (op. cit. p. 15), lo llama en otro poema, es la última cifra, el mensaje final grabado en la carne ("ambiciosa ceniza"); el epitafio, escarmiento para futuros peregrinos de paso:

Este en forma elegante, oh peregrino, de pórfido luciente dura llave, el pincel niega al mundo más süave, que dio espíritu a leño, vida a lino.

Su nombre, aun de mayor aliento dino que en los clarines de la Fama cabe, el campo ilustra de ese mármol grave: venéralo y prosigue tu camino.

Yace el Griego. Heredó Naturaleza Arte; y el Arte, estudios. Iris, colores.

Febo, luces - si no sombras, Morfeo-.

Tanta urna, a pesar de su dureza; lágrimas beba, y cuantos suda olores corteza funeral de árbol sabeo. ${ }^{80}$

\footnotetext{
7.9 Francisco de Quevedo, Obras completas, I, ed. José Manuel Blecua (Barcelona: Planeta, 1968), p. 10.

80 Don Luis de Góngora, "Inscripción para el sepulcro de Domínico Greco", en Dámaso Alonso, Góngora y el Polifemo, v. 2 (Madrid: Gredos, 1967), p. 172.
} 
En su rescate de la historia, en sus peregrinajes en busca del origen perdido, lo que encuentra Carpentier son las ruinas, los monumentos desmantelados, los epitafios - "Buscas en Roma a Roma, joh, peregrino!" La única presencia son las ruinas: hierática y monumental, artificiosa y arcaica, la prosa de Carpentier será la erección del nuevo monumento, la cifra, el epitafio inscripto entre un 7 y un 8, entre un domingo y un lunes, inscripto también en su propia máscara.

Todos los recursos utilizados por Carpentier para evocar lo fantástico durante estos años hay que verlos dentro de esta magia barroca que se ha venido analizando - fantasías conjuradas en nombre de una fe que es el mayor artificio, la impostura todo envolvente; el teatro litúrgico, sacramental, donde los opuestos e irreconciliables polos de las contradicciones (ilusorias) se conjugan - se con-juegan. Es el espacio de la literatura que no satisface al Carpentier del prólogo, pero en el que se inscriben todos sus gestos, y que lo absorbe y cifra.

Las contradicciones vistas a lo largo de este estudio desmoronan el centro teórico del ensayo-prólogo de El reino de este mundo, pero a ellas debemos la tiqueza de ese relato, y además Los pasos perdidos, novela del desengaño, en que se ponen de manifiesto las falacias de lo "real maravilloso americano", y que lleva a Carpentier a abandonar la literatura fantástica; en que la reflexividad y el desdoblamiento agrietan la "fe" y. muestran a través de las fisuras el vacío. En los relatos de los años cuarenta (Carpentier denomina así El reino de este mundo a pesar de su longitud) serán esos seres despersonalizados, figuras de retablo, los que se verán atrapados en las circularidades de viajes por las selvas del continente, saltando de isla en isla, gesticulando impotentes, pero surgirán otras que abrirán nuevos cauces a la ficción. En las novelas que siguen se asumirán las contradicciones. El tránsito de las teorías de "lo real maravilloso americano" a Los pasos perdidos no podía ser más significativo. Ante la patente contradicción implícita en el primero, la de no poder entablar entre la "cultura" y el escritor un diálogo que no implique la reificación, la distancia, la ruptura; al no poder convertirse en "autóctono y salvaje" en el momento de la escritura, la única posibilidad es el desdo. blamiento del yo, de la máscara del prólogo. Porque al desdoblar a ese Autor (en el sentido calderoniano de $E l$ gran teatro del mundo), al objetivarlo, Carpentier lo pone en el mismo plano de ese otro que permanece impenetrable y ajeno. ${ }^{81}$ El Libro de la Gran Sabana, crónica inconclusa de

81 Ver en la "Introduction à l'oeuvre de Marcel Mauss" (Sociologie et Anthropologie, op. cit.) la discusión de Lévi-Strauss sobre este problema en términos del antropólogo. 
los peregrinajes de Carpentier por las selvas venezolanas, y Los pasos perdidos, novela autobiográfica, serán la respuesta a la interrogante que el prólogo de El reino de este mundo abre. ${ }^{82}$

Cornell University

RobErTo GonzÁlez ECHEVARría

82 Lo dicho aquí no quiere decir que no se puedan devivar del texto de El reino de este mundo, y demás relatos de los años cuarenta, conclusiones o comentarios sobre la historia política y social del Caribe. Sabemos, gracias a los trabajos de Bastide, que el cimarronaje y que las sociedades cimarronas representaron un tipo de oposición cultural por parte de los esclavos contra la violencia de la esclavitud. Puede verse, además, en algunos personajes negros de esos relatos - $\mathrm{Ti}$ Noel, Gregorio, Panchón, Cimarrón- una característica que ha sido descrita con gran elocuencia por el ilustre poeta haitiano René Depestre: "La esclavitud despersonalizó al hombre africano deportado a las Antillas. El principal objetivo de ese modo de producción era extraer de la mano de obra esclavizada la energía para crear riquezas materiales. El hombre negro se convirtió así en hombre-carbón, en hombre-combustible, en hombre-nada [...] Este fantástico proceso de cosificación y de asimilación implicaba la pérdida total de mi identidad de hombre, la aniquilación sociológica de mi ser. No es po: casualidad que el mito del zombi haya nacido precisamente en las Antillas, ya que la historia de este archipiélago es la de un proceso de zombificación del hombre negro". "Problemas de la identidad del hombre negro en las literaturas antillanas", Diez años de la Revista Casa de las Américas (La Habana: Casa de las Américas, 1970), p. 54. De Roger Bastide, ver Les Amériques Noires. Les civilisations Africaines dans le Nouveau Monde (París: Payot, 1967). 
